\section{Pacific Northwest}

National Laboratory

Operated by Battelle for the

U.S. Department of Energy

\title{
Characterization of TRU Inventories in $G$ and $H$ Cells, 327 Building Using a Neutron Instrument Pod
}

\author{
R.I. Scherpelz \\ G.M. Mapili \\ D.S. Dutt
}

January 2003

Prepared for the U.S. Department of Energy under Contract DE-AC06-76RL01830 


\title{
DISCLAIMER
}

This report was prepared as an account of work sponsored by an agency of the United States Government. Neither the United States Government nor any agency thereof, nor Battelle Memorial Institute, nor any of their employees, makes any warranty, express or implied, or assumes any legal liability or responsibility for the accuracy, completeness, or usefulness of any information, apparatus, product, or process disclosed, or represents that its use would not infringe privately owned rights. Reference herein to any specific commercial product, process, or service by trade name, trademark, manufacturer, or otherwise does not necessarily constitute or imply its endorsement, recommendation, or favoring by the United States Government or any agency thereof, or Battelle Memorial Institute. The views and opinions of authors expressed herein do not necessarily state or reflect those of the United States Government or any agency thereof.

\author{
PACIFIC NORTHWEST NATIONAL LABORATORY \\ operated by \\ BATTELLE \\ for the \\ UNITED STATES DEPARTMENT OF ENERGY \\ under Contract DE-AC06-76RL01830
}

This document was printed on recycled paper. 


\section{Characterization of TRU Inventories in $G$ and $H$ Cells, 327 Building Using a Neutron Instrument Pod}

January 2003

Prepared for

the U.S. Department of Energy

under Contract DE-AC06-76RL01830

Pacific Northwest National Laboratory

Richland, Washington 99352 


\section{Summary}

An instrument pod has been designed and constructed to estimate the quantity of transuranic (TRU) isotopes present in hot cells in Hanford's 327 Building. This estimate is required to assign the proper waste classification for ultimate disposal of the hot cell.

The instrument pod consists of a cylindrical polyethylene moderator containing three neutron detectors. The pod diameter was chosen to allow the pod to be deployed through a 7-in. port in the hot cell wall. A polyethylene traverse pipe, long enough to extend through the interior of the cell, was designed for insertion through the hot cell port, allowing the pod to be positioned inside the cell. The neutron detectors chosen for the pod were fission chambers, which provides acceptable sensitivity to neutrons with excellent rejection of gammas even in high-contamination cells.

The neutron pod was tested and calibrated in Pacific Northwest National Laboratory's Low Scatter Room, using a ${ }^{252} \mathrm{Cf}$ source in both unmoderated and $\mathrm{D}_{2} \mathrm{O}$-moderated configurations. The calibration configurations were then modeled using the computer code MCNP to arrive at a calibration constant that relates the neutron flux incident on the pod to neutron count rate.

The neutron pod was used in the $\mathrm{G}$ and $\mathrm{H}$ hot cells in the 327 Building. These hot cells had been decommissioned and are slated for disposal. For each hot cell, the neutron pod was positioned at about 10 locations inside the cell and count rates were recorded. The recorded count rates were all very close to background levels, since substantial cleanup effort had been expended in each cell.

MCNP modeling was then performed, with plutonium distributed inside the cell in several likely distributions. The models produced values of neutron count rate per gram $\mathrm{Pu}$ in the cell. These values were then applied to the measured count rates to determine the quantity of $\mathrm{Pu}$ that is in the cell.

The best estimate for the contents of $\mathrm{G} \mathrm{Cell} \mathrm{is} 1.18 \mathrm{~g} \mathrm{Pu}$, with an uncertainty bound ranging from $0 \mathrm{~g}$ to $2.75 \mathrm{~g} \mathrm{Pu}$. For $\mathrm{H} \mathrm{Cell}$, the best estimate is $1.03 \mathrm{~g} \mathrm{Pu}$, with an uncertainty bound ranging from $0 \mathrm{~g}$ to $2.80 \mathrm{~g} \mathrm{Pu}$. The best estimates of the TRU activity, as a function of waste mass in the entire cell, is $2.34 \mathrm{nCi} / \mathrm{g}$ for $\mathrm{G}$ Cell and $3.87 \mathrm{nCi} / \mathrm{g}$ for $\mathrm{H}$ Cell. 



\section{Acknowledgments}

The authors appreciate the assistance of John Sachs and Paul Tomeraasen for design and construction of the pod; Dan Haggard for advice and review; Ray Stevens, and Bill Jasen for support on the Hanford operations side; Jan Tarantino for technical editing; and Kathi Eder for document production. 


\section{Contents}

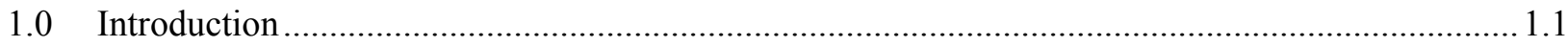

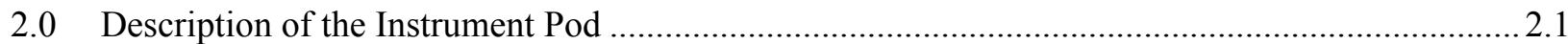

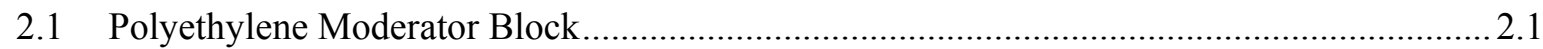

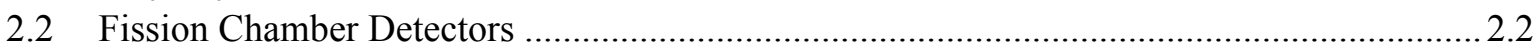

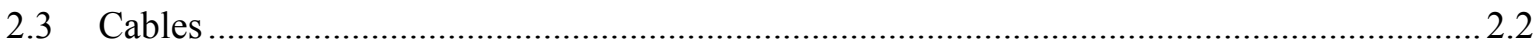

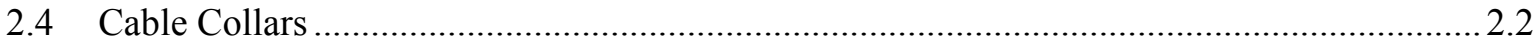

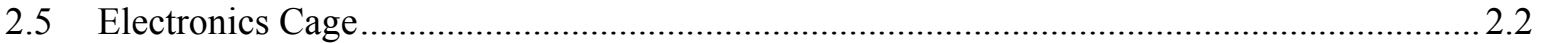

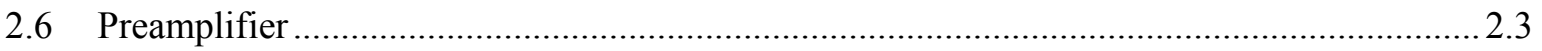

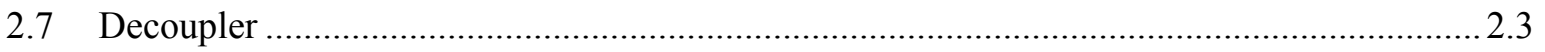

2.8 Pushrod

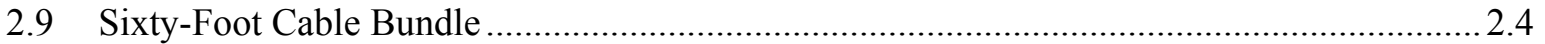

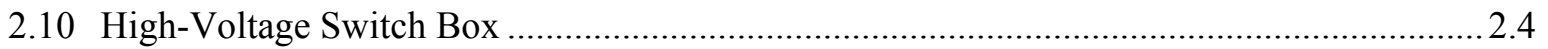

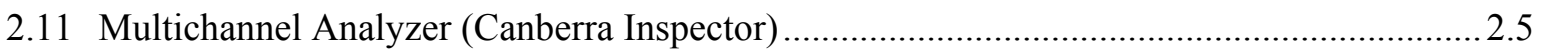

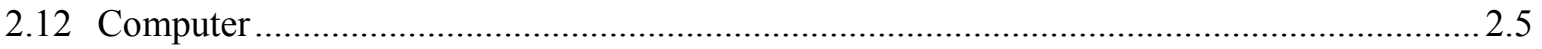

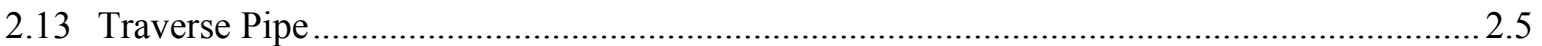

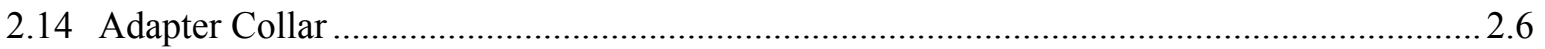

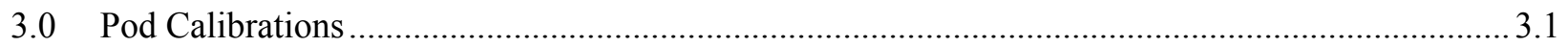

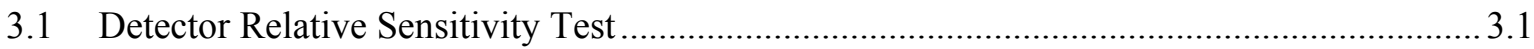

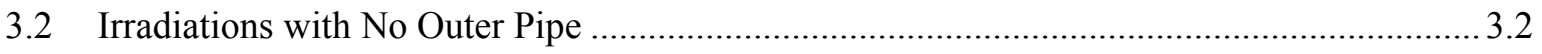

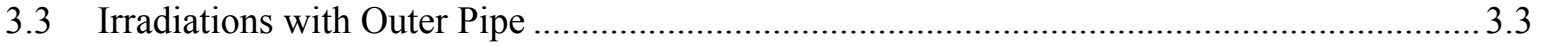

4.0 Modeling Detector Responses in the 318 Building Low Scatter Room..................................... 4.1

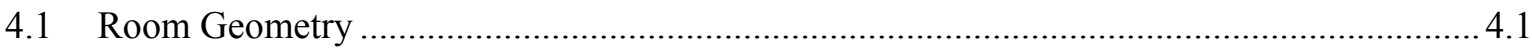

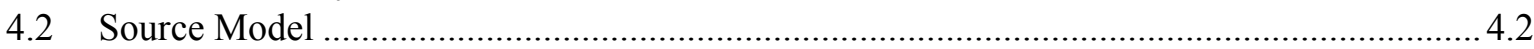

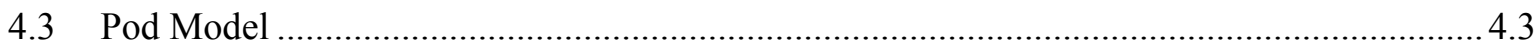

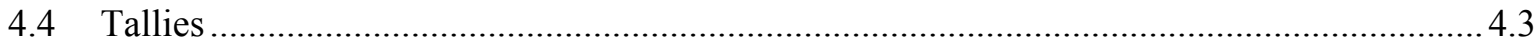

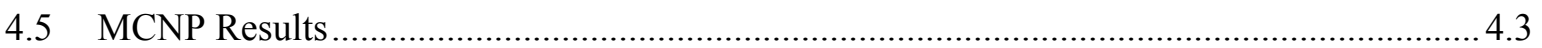

4.6 Comparison of Measured and Modeled Count Rates........................................................... 4.4

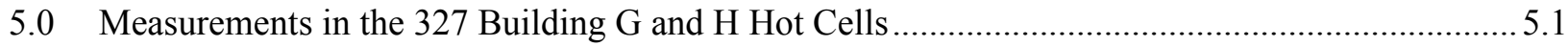

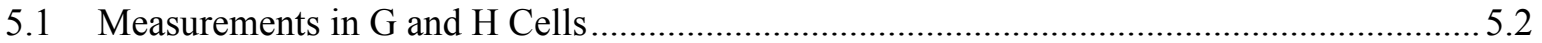

5.2 Determination of Measured Neutron Count Rates ................................................................. 5.4

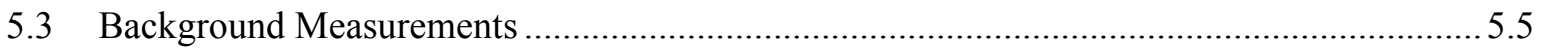

5.4 Evaluated Neutron Count Rates ............................................................................... 5.7

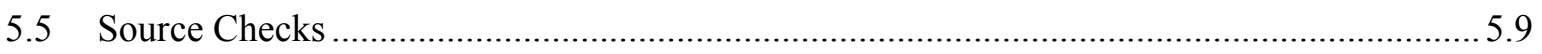

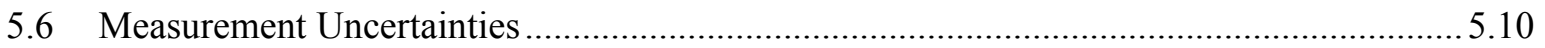


6.0 Modeling Detector Responses in the 327 Building Hot Cells................................................. 6.1

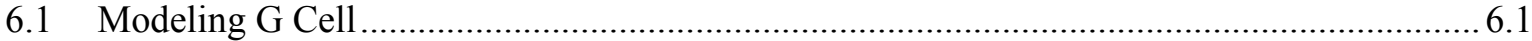

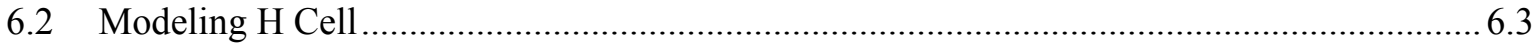

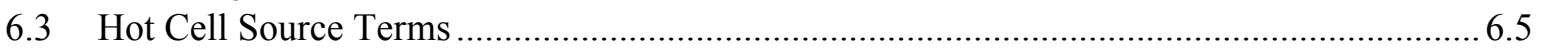

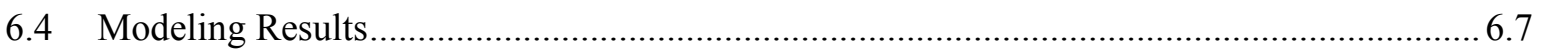

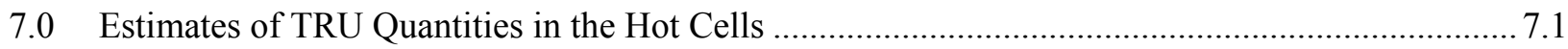

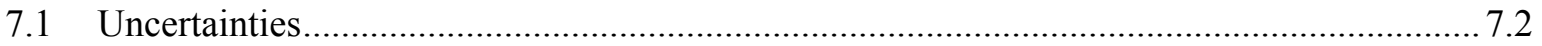

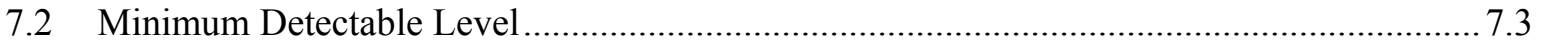

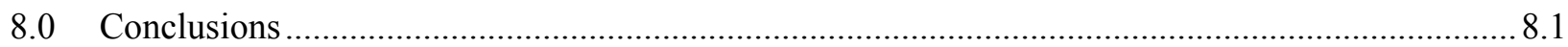

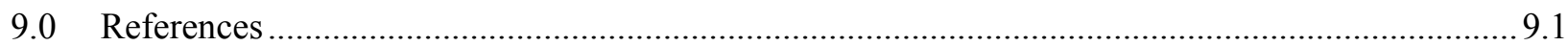




\section{Figures}

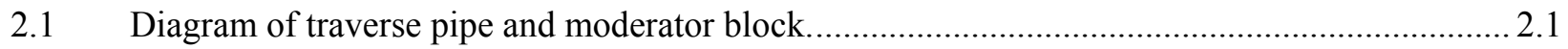

2.2 Moderator block showing positions of detectors inside the block ............................................. 2.2

$2.3 \quad$ Electronics cage mounted on end of moderator block .............................................................. 2.3

2.4 Photo of high-voltage switch box sitting on top of the MCA. ................................................... 2.4

2.5 Computer with MCA and high-voltage switch box................................................................. 2.5

4.1 Model of the LSR showing the $\mathrm{z}$ (vertical) and $\mathrm{y}$ (horizontal) dimensions................................ 4.2

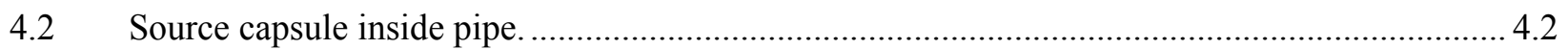

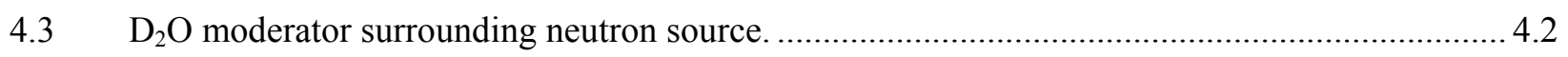

4.4 Model of the pipe wall, moderator block, and detector. ......................................................... 4.3

$5.1 \quad$ Hot Cells in the west end of the 327 Building Canyon............................................................. 5.1

$5.2 \quad$ Workers inserting the traverse pipe into a port in G Cell. ..................................................... 5.2

5.3 Handle of pod extending from traverse pipe in a G Cell port. ................................................... 5.3

5.4 Discriminating between background and neutron events. .................................................. 5.5

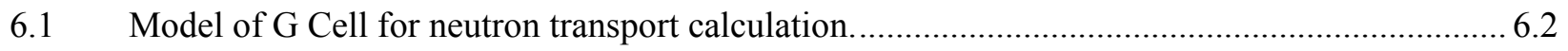

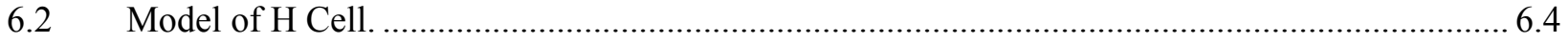




\section{Tables}

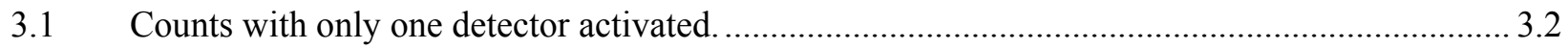

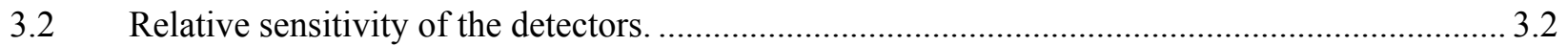

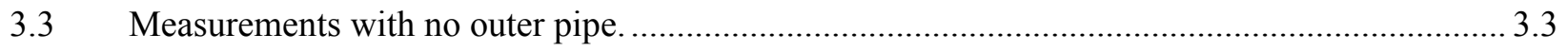

3.4 Measurements with pod covered by outer pipe. ….................................................................. 3.3

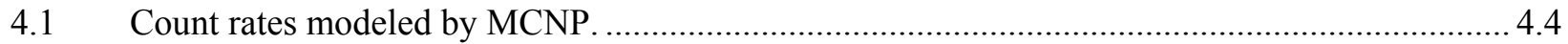

4.2 Comparison of measurements to modeled count rates........................................................... 4.5

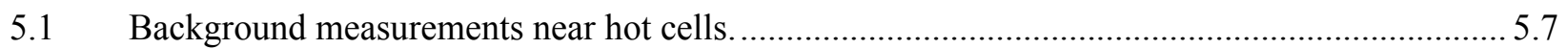

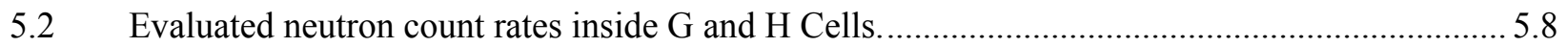

5.3 North-south positions of measurement locations in $\mathrm{G}$ and H Cells......................................... 5.9

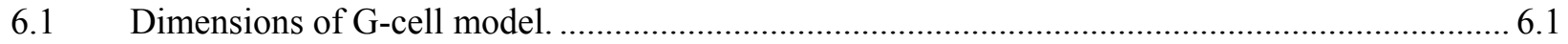

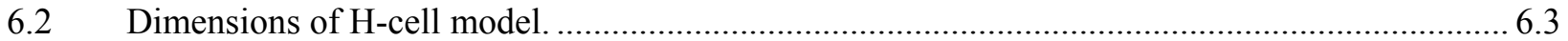

6.3 Isotopic composition of plutonium used in hot cell model....................................................... 6.5

6.4 Contamination regions in G Cell for "realistic" distribution. .................................................... 6.6

6.5 Contamination regions in H Cell for "realistic" distribution. ................................................... 6.7

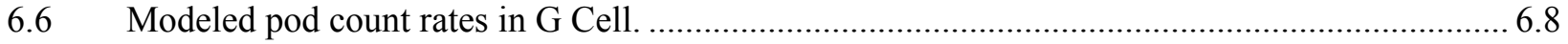

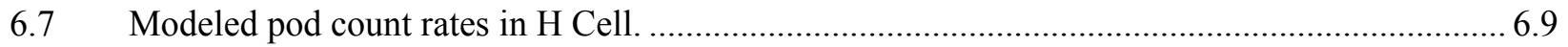

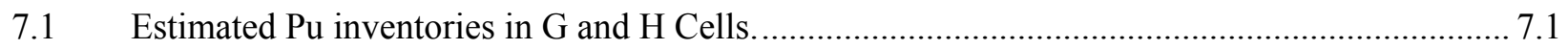

7.2 Best estimates and upper/lower bound estimates for TRU inventories. .................................. 7.3 


\subsection{Introduction}

This report describes the development of a neutron pod for the measurement of transuranic (TRU) quantities in hot cells. The report documents pod measurements that staff of the Pacific Northwest National Laboratory (PNNL) conducted in the Hanford Site's 327 Building G and H Cells in October and November 2002 to determine the TRU contents of the cells. The report describes the pod design, calibration, and measurements; background measurements that were performed near the hot cells; data analysis of the measurements; the computer code MCNP modeling of the cells; and the determination of TRU contents in the cells.

Neutron detection is a useful method for measuring TRU because neutrons are not emitted by non-TRU isotopes likely to be found in a hot cell. Thus, the presence of neutrons is a reliable indicator of the presence of TRU.

The neutron detector chosen for the instrument pod is a "fission chamber," which is a proportional counter containing a thin coating of highly enriched uranium on the inside surface of its cylindrical wall. Incoming neutrons create fissions in the uranium, and the recoiling fission products create a substantial signal that is recorded in the detector electronics. Fission chambers are less sensitive to neutrons than commonly used neutron detectors such as ${ }^{3} \mathrm{He}$ tubes, but they were chosen for this application because they are insensitive to gamma radiation. Even radiation fields with an intensity of $1000 \mathrm{R} / \mathrm{h}$ of gamma will not affect the performance of a fission chamber in counting neutrons.

Neutrons are emitted from TRU isotopes either by spontaneous fission, or by $(\alpha, n)$ reactions with lowatomic-number elements nearby. The average energy of these emitted neutrons is typically about $2 \mathrm{MeV}$. The fission chamber, however, is primarily sensitive to thermal-energy neutrons, so they must be moderated before they can be detected by the fission chambers. Moderation occurs by scattering off material containing hydrogen, such as plastic or concrete (or water). The instrument pod incorporates a moderator in the form of a plastic cylinder, with a diameter to fit inside the port of a hot cell. This plastic cylinder has holes to accommodate the fission chambers. Preliminary calculations were performed to optimize the configuration of the moderator and detectors, given the constraint of a limit on the outer diameter. This design effort arrived at a configuration with three fission chambers contained within the moderator block.

After construction in PNNL's shops, the neutron pod was tested and calibrated in the Low Scatter Room (LSR) of PNNL's 318 Building. The pod was then used for measurements in the G and H Cells of the 327 Building. Radiation transport modeling using the MCNP computer code was performed to evaluate the measurement results.

This report describes the design of the detector pod and its calibration. It then documents the measurements performed in the $\mathrm{G}$ and $\mathrm{H}$ Cells, describes the radiation transport modeling and data analysis, and then discusses the estimation of TRU inventories in the cells based on the measurement and modeling. 


\subsection{Description of the Instrument Pod}

The instrument pod consists of the 18-in.-long moderator block, with an outer diameter of 5.14 in., containing the detectors; and a 10-in.-long electronics cage attached to one end. The electronics cage holds a preamplifier and a decoupler, which routes high voltage to the three detectors and combines the signals from the three detectors into one train of electronic pulses that are fed back to the amplifier and multichannel analyzer (MCA).

A cable bundle extends from the pod's electronics cage to the detector electronics, including a highvoltage power supply, a preamplifier power supply, an amplifier, and a multichannel analyzer. All of these functions are actually contained in one compact unit, which operates with a laptop computer. Figure 2.1 shows the overall design of the neutron pod and traverse pipe.

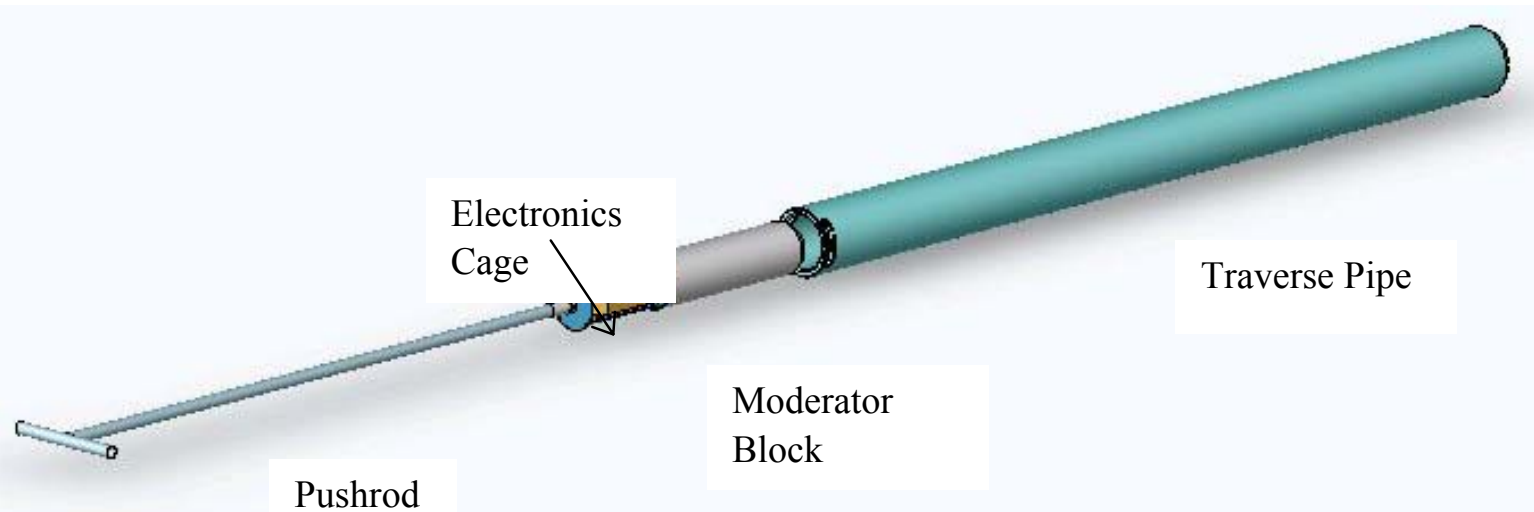

Figure 2.1. Diagram of traverse pipe and moderator block.

\subsection{Polyethylene Moderator Block}

This unit provides neutron moderation to increase the sensitivity of the detectors. It was machined from a block of ultra-high molecular weight (UHMW) polyethylene (density $0.94 \mathrm{~g} / \mathrm{cm}^{3}$ ), with outer dimensions of 18-in. long by 5.14-in. diameter. There is a slight taper in the corner of the leading edge to ease insertion into a pipe. Three holes were drilled in the block to accommodate the three detectors. The holes were positioned lengthwise so that the center of the active volume of the detector is at the center of the block's cylindrical axis. Figure 2.2 shows the general design of the moderator block. 


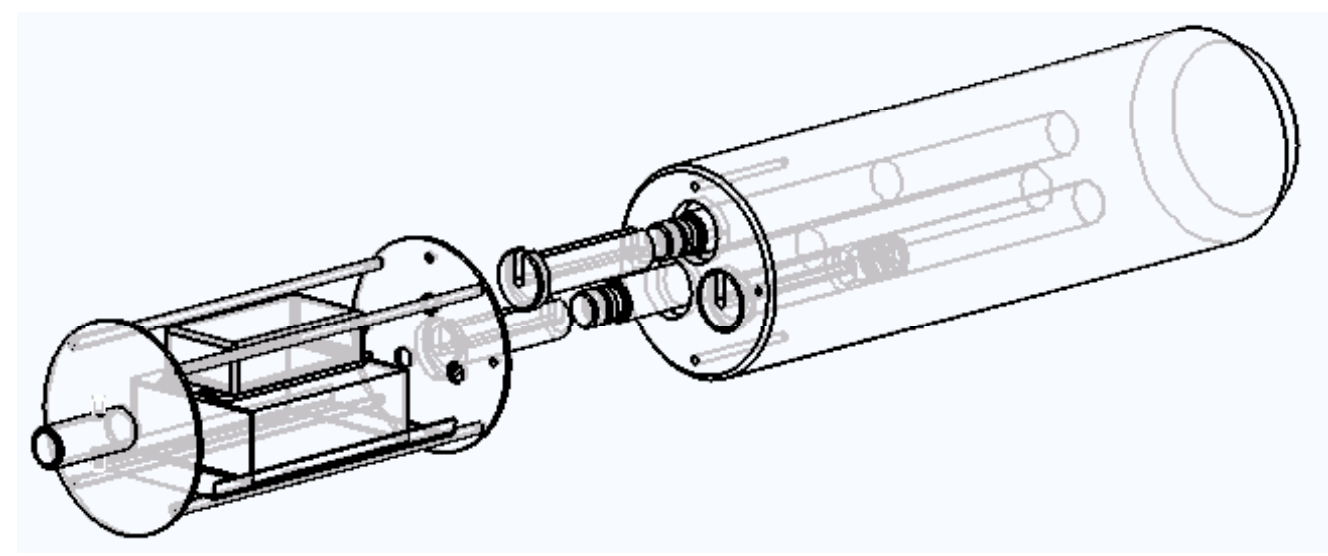

Figure 2.2. Moderator block showing positions of detectors inside the block.

\subsection{Fission Chamber Detectors}

These detectors are proportional counters containing a thin coating of highly enriched uranium on the inner wall. The detector has an outer diameter of 1.03 in., and an overall length of 8 in., with an HN connector on one end. The sensitive length is 5.0 in. Each detector contains $0.139 \mathrm{~g}$ uranium $(0.158 \mathrm{~g}$ $\mathrm{UO}_{2}$ ). The uranium is enriched to $93 \%{ }^{235} \mathrm{U}$.

\subsection{Cables}

A short cable leads from each detector and connects to the decoupler box. At the detector end, the cable is fitted with an $\mathrm{HN}$ connector. At the other end is an SHV connector.

\subsection{Cable Collars}

A plastic collar is supplied for each cable leading out of the moderator block. These collars fill holes that otherwise would decrease the moderating capability of the polyethylene block.

\subsection{Electronics Cage}

The electronics cage holds the preamplifier and decoupler. The faceplate at one end has holes to accommodate screws that fasten the cage to the moderator block. At the other end, there is an attachment for the pushrod. At the moderator block end, three holes are drilled to accommodate the cables leading from the three detectors. At the pushrod end, a hole accommodates the 60 -ft cable bundle, allowing it to pass through the center of the pushrod. Figure 2.3 shows the electronics cage positioned on the end of the moderator block. 


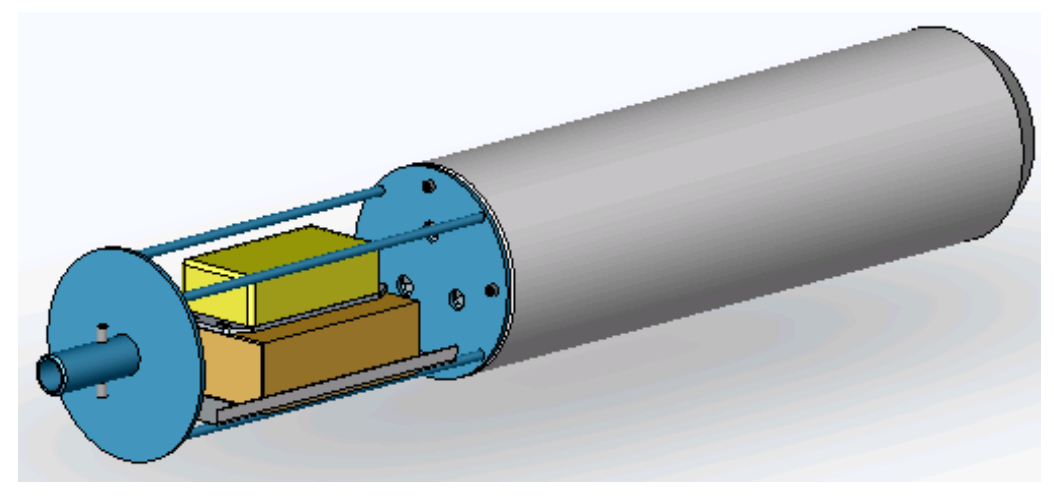

Figure 2.3. Electronics cage mounted on end of moderator block.

\subsection{Preamplifier}

This electronic module routes high voltage into the detectors and receives the signal from the detectors, amplifying the signal pulses. An SHV connector at one end is connected via a short cable to the decoupler box. A BNC on the other end, labeled Energy, is connected to the signal cable in the $60-\mathrm{ft}$ cable bundle. A short cable leading from the preamplifier with a 9-pin connector mates to a 9-pin connector on the $60-\mathrm{ft}$ cable bundle to provide $12-\mathrm{V}$ power for the electronics. This unit is a standard product of EG and G ORTEC, model 142-PC.

\subsection{Decoupler}

The decoupler separates the high voltage from the signal pulses that travel together over the cable from the detector. It has an SHV connector that accepts a short cable leading to the preamplifier. It also has three SHV connectors on the moderator block end to accept the short cables from the three detectors, and three SHV connectors on the other end to connect to the $60-\mathrm{ft}$ cable bundle. This module was designed and assembled at PNNL, using commercially available components.

\subsection{Pushrod}

The pushrod allows the operator to insert the pod into the traverse pipe to a controlled position. The pushrod is $65 \mathrm{in.} \mathrm{long.} \mathrm{It} \mathrm{has} \mathrm{a} \mathrm{locking} \mathrm{collar} \mathrm{on} \mathrm{one} \mathrm{end} \mathrm{to} \mathrm{fasten} \mathrm{to} \mathrm{the} \mathrm{end} \mathrm{of} \mathrm{the} \mathrm{electronics} \mathrm{cage.}$ There is a T-handle at the other end. The pushrod is hollow to accommodate the 60 - $\mathrm{ft}$ cable bundle inside it. A slot near the T-handle lets the cable bundle exit. The pushrod can be disconnected from the electronics cage to allow easier packing, but the cable bundle cannot be easily extracted from it. 


\subsection{Sixty-Foot Cable Bundle}

The cable bundle carries signals and power from the system electronics to the pod. It was made 60 - $\mathrm{ft}$ long to allow flexibility in placing the system electronics. The cable bundle has five components:

- Three high-voltage cables, made of RG-59 shielded coaxial cable, with SHV connectors on both ends. These cables carry high voltage for the three detectors, typically 800 volts. At the pod end, they connect to the decoupler box. At the electronics end, they connect to the high-voltage switch box.

- Signal cable, made of RG-59 shielded coaxial cable, with BNC connectors at both ends. This cable carries the signal from the preamplifier. At the pod end, it connects to the red cable labeled "Energy," with two terminators in between.

- Preamp power cable: this cable carries 12-volt power from the system electronics to the preamplifier. It has 9-pin connectors on each end. At the pod end, it connects to the 9-pin connector coming from the preamplifier. At the electronics end, it connects to the 9-pin connector coming from the white cable out of the MCA.

The five cables in the cable bundle are sheathed in a flexible braided wrapping that keeps them together and prevents tangling and snagging.

\subsection{High-Voltage Switch Box}

This small box, located near the electronics end, allows the high voltage to be selectively applied to any one detector or all three detectors. Four SHV connectors are mounted on the rear face of the box; one connector accepts the white high-voltage cable from the MCA, while the other three accept the highvoltage cables from the 60 -ft cable bundle. On the front face is a round knob for a switch with five positions, one for each of the three individual detectors, one for all three detectors, and one for "off." Figure 2.4 shows the front face of the switch box.

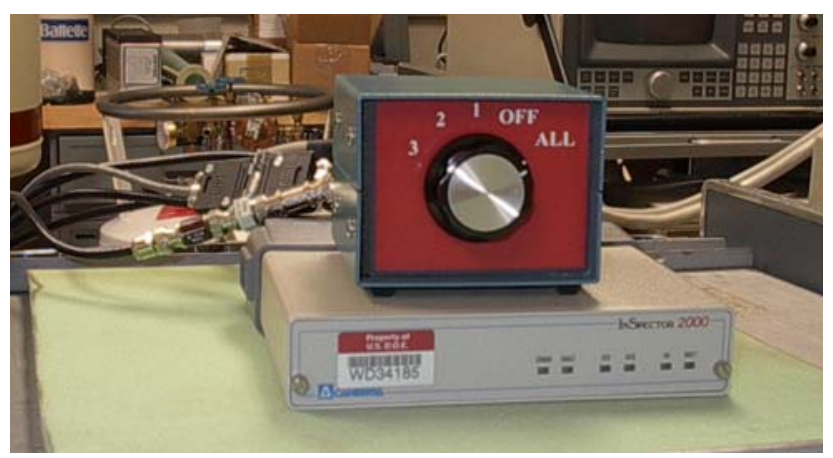

Figure 2.4. Photo of high-voltage switch box sitting on top of the MCA. 


\subsection{Multichannel Analyzer (Canberra Inspector)}

This compact electronics unit contains a high-voltage supply, signal amplifier and multichannel analyzer. A thick white cable, supplied by Canberra, connects to the back of the MCA and connects to the $60-\mathrm{ft}$ cable bundle and high-voltage switch box. The MCA can be powered by a camcorder battery for operations requiring only a few hours, but it can also be plugged into a power source for long-term continuous operation. Figure 2.4 also shows the MCA.

\subsection{Computer}

The computer communicates with the MCA via a USB interface. It contains GENIE-2k software provided by Canberra to operate the MCA. All MCA functions are controlled by the computer, no adjustments can be made without the computer. The computer also allows storage of the pulse-height spectra from a neutron measurement. Figure 2.5 shows the system computer.

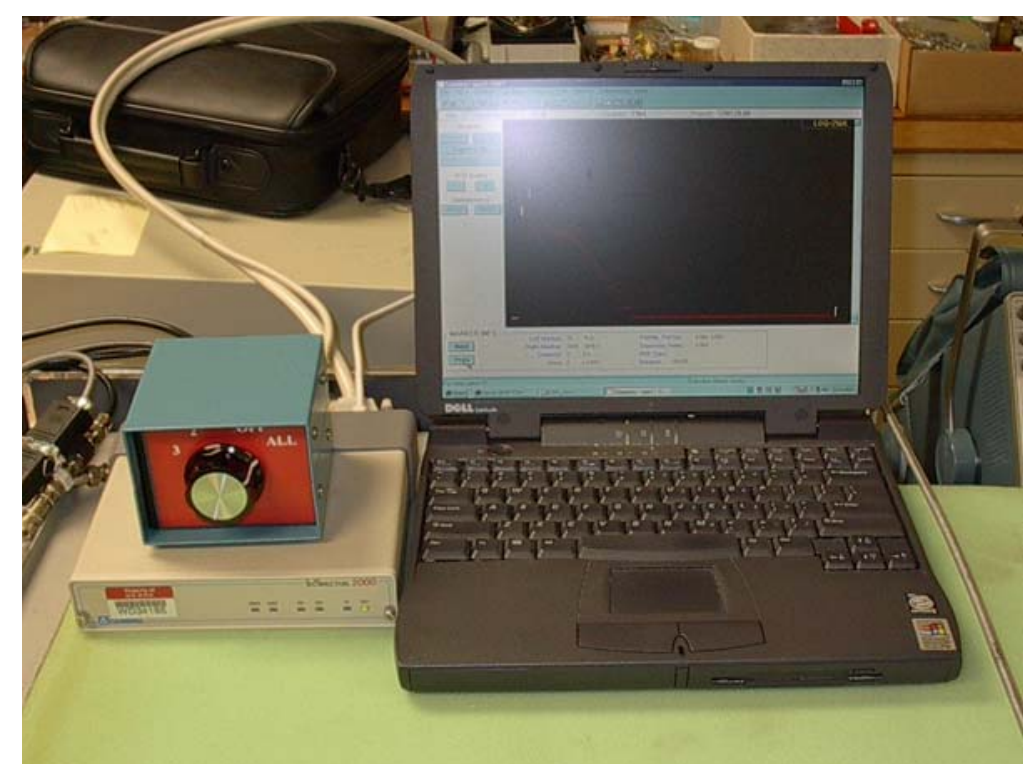

Figure 2.5. Computer with MCA and high-voltage switch box.

\subsection{Traverse Pipe}

The traverse pipe will extend the width of a hot cell, through a cell port. The pipe is $7 \mathrm{ft} 6 \mathrm{in}$. long, and is made from UHMW polyethylene. The outer diameter is $6.63 \mathrm{in}$. and an inner diameter is $5.14 \mathrm{in}$. The inner diameter was chosen to allow a relatively snug fit for the pod, but still allow the pod to slide easily inside it. The pipe material was selected to provide adequate rigidity, but also neutron moderation to enhance the sensitivity of the detectors. The traverse pipe fits inside the adapter collar, which is itself inserted into the cell port. The pipe has handle slots cut into the end to allow manipulation. 


\subsection{Adapter Collar}

The adapter collar fits inside the cell port and accommodates the traverse pipe. The collar is made of steel. It has an inner diameter of 6.63 in., just enough to accommodate the traverse pipe. It has two handle slots cut into the outside end. 


\subsection{Pod Calibrations}

Measurements were performed in the 318 Building Low Scatter Room (LSR) to characterize the response of the detector pod. The LSR is used for the calibration of radiation detection instrumentation, and is particularly effective for neutron calibrations. The room is large, approximately $10 \mathrm{~m} \times 9 \mathrm{~m} \times 15 \mathrm{~m}$, and the position of the neutron source during irradiation is approximately at the geometrical center of the room. This configuration produces a "low-scatter" condition, where nearly all of the neutrons arriving at the irradiation position have traveled directly there from the neutron source, and the effect of moderated neutrons that scattered off the walls is minimal. This low-scatter condition produces a well-defined energy distribution, which is an important requirement for calibration.

There are two neutron sources available in the LSR: identification numbers of 318-356 and 318-016. Both are ${ }^{252} \mathrm{Cf}$ sources, with activities traceable to the National Institute of Standards and Technology (NIST). Source 318-356 has a neutron emission rate of $5.04 \times 10^{8} \mathrm{n} / \mathrm{s}$, and source $318-016$ has a neutron emission rate of $1.81 \times 10^{6} \mathrm{n} / \mathrm{s}$ (both effective July 16, 2002). These values were found by decaying the NIST-traceable values from their reference dates to July 16, 2002, using a half-life of 2.646 years. The neutron emission rate of $318-016$ also includes a $19.4 \%$ correction to account for the build-in of ${ }^{250} \mathrm{Cf}$, since the source is an old source. The ${ }^{250} \mathrm{Cf}$ introduces a neutron component that decays with a 13.1-year half-life. The SCR staff estimates that the actual neutron emission rate for 318-016 is $19.4 \%$ higher than the NIST-traceable value.

The neutron sources can be used in two irradiation configurations: unmoderated and moderated by a 30 -cm diameter sphere of $\mathrm{D}_{2} \mathrm{O}$. These two configurations provide two different energy distributions - $\mathrm{a}$ high-energy fission spectrum, and a lower-energy moderated fission spectrum. Both configurations were used in this study.

\subsection{Detector Relative Sensitivity Test}

The first test was to check the relative sensitivity of the three fission chambers. For these tests, the pod was irradiated using only the moderator block around the detectors, without being enclosed by an outer pipe. The pod was positioned with its cylindrical axis horizontal and perpendicular to the line between the pod and the source. The "active center" of the pod, that is the point on the cylindrical axis of the pod which is on the same plane as the active centers of the three detectors, was located $100 \mathrm{~cm}$ from the neutron source.

Source 318-356 was used in an unmoderated configuration. Three sets of irradiations were performed, with the pod rotated approximately 120 degrees before each new set, so a different detector was closest to the source for each irradiation set. Each set included three exposures; for each exposure the high voltage was applied to only one of the detectors. Thus separate readings were taken for each of the three detectors in each of the three orientations. The results are presented in Table 3.1. 
Table 3.1. Counts with only one detector activated.

\begin{tabular}{|c|c|c|c||}
\hline $\begin{array}{c}\text { Detector Oriented } \\
\text { Toward Source }\end{array}$ & $\begin{array}{c}\text { Detector } \\
\text { Activated }\end{array}$ & Live Time(s) & $\begin{array}{c}\text { Neutron } \\
\text { Counts }\end{array}$ \\
\hline 1 & 1 & 120 & 111,508 \\
\hline 1 & 2 & 120 & 86,797 \\
\hline 1 & 3 & 120 & 81,821 \\
\hline 2 & 1 & 120 & 88,293 \\
\hline 2 & 2 & 120 & 108,480 \\
\hline 2 & 3 & 120 & 83,989 \\
\hline 3 & 1 & 120 & 88,562 \\
\hline 3 & 2 & 120 & 88,245 \\
\hline 3 & 3 & 120 & 101,445 \\
\hline
\end{tabular}

To determine whether a possible difference in the sensitivity of the detectors can produce a directional response for the pod, the three count rates for the individual detectors were summed for each orientation, and presented in Table 3.2. The right-hand column of Table 3.2 also shows the count rate divided by the neutron emission rate of the source.

Table 3.2 shows that the detectors have essentially identical sensitivities, with the small differences within the measurement uncertainties.

Table 3.2. Relative sensitivity of the detectors.

\begin{tabular}{|c|c|c|c|c||}
\hline Detector & $\begin{array}{c}\text { Total Live } \\
\text { Time(s) }\end{array}$ & $\begin{array}{c}\text { Total } \\
\text { Counts }\end{array}$ & $\begin{array}{c}\text { Total Count } \\
\text { Rate (c/s) }\end{array}$ & $\begin{array}{c}\text { Sensitivity } \\
(\mathbf{c} / \mathbf{s} \text { per n/s) }\end{array}$ \\
\hline 1 & 360 & 280,126 & 2334 & $4.64 \mathrm{E}-06$ \\
\hline 2 & 360 & 280,762 & 2340 & $4.65 \mathrm{E}-06$ \\
\hline 3 & 360 & 278,251 & 2319 & $4.60 \mathrm{E}-06$ \\
\hline
\end{tabular}

\subsection{Irradiations with No Outer Pipe}

Measurements were also performed under the normal operating condition, with high voltage supplied to all three detectors, but without the outer pipe enclosing the moderator block. The results of these measurements are shown in Table 3.3. 
Table 3.3. Measurements with no outer pipe.

\begin{tabular}{|c|c|c|c|c|c|c|}
\hline $\begin{array}{c}\text { Neutron } \\
\text { Source ID }\end{array}$ & $\begin{array}{c}\text { Source } \\
\text { Configuration }\end{array}$ & $\begin{array}{c}\text { Detector Oriented } \\
\text { Toward Source }\end{array}$ & $\begin{array}{c}\text { Live } \\
\text { Time(s) }\end{array}$ & Net Counts & $\begin{array}{c}\text { Count Rate } \\
(\mathbf{c} / \mathbf{s})\end{array}$ & $\begin{array}{c}\text { Sensitivity } \\
(\mathbf{c} / \mathbf{s} \text { per n/s) }\end{array}$ \\
\hline $318-356$ & Unmoderated & 1 & 120 & 256,843 & 2140 & $4.25 \mathrm{E}-06$ \\
\hline $318-356$ & Unmoderated & 3 & 120 & 254,175 & 2118 & $4.21 \mathrm{E}-06$ \\
\hline $318-356$ & Unmoderated & 2 & 120 & 254,674 & 2122 & $4.21 \mathrm{E}-06$ \\
\hline
\end{tabular}

Comparing the last columns in Tables 3.2 and 3.3 shows that the sensitivity is slightly lower when all three detectors are activated, compared to the detectors activated individually and their count rates summed. The difference in sensitivities is approximately $9.6 \%$. This difference is probably caused by the electronics. However, in actual practice, all three detectors will be used together at all times, so calibrations performed using all three detectors will be applicable to field measurement conditions.

\subsection{Irradiations with Outer Pipe}

Irradiations were also performed with a 4-ft-long section of polyethylene pipe over the moderator block to closely simulate the response of the detectors in a hot-cell measurement condition. The test pipe was made of the same polyethylene that is used in the traverse pipe. Irradiations were performed with both neutron sources, in both unmoderated and $\mathrm{D}_{2} \mathrm{O}$-moderated conditions. Table 3.4 shows the measurements performed with an outer pipe over the moderator block. As with the other measurements, the detector pod was positioned with its active center $100 \mathrm{~cm}$ from the ${ }^{252} \mathrm{Cf}$ source.

Table 3.4. Measurements with pod covered by outer pipe.

\begin{tabular}{|c|l|c|c|c|c|c||}
\hline $\begin{array}{c}\text { Neutron } \\
\text { Source ID }\end{array}$ & $\begin{array}{c}\text { Source } \\
\text { Configuration }\end{array}$ & $\begin{array}{c}\text { Detector Oriented } \\
\text { Toward Source }\end{array}$ & Live Time(s) & $\begin{array}{c}\text { Net } \\
\text { Counts }\end{array}$ & $\begin{array}{c}\text { Count Rate } \\
(\mathbf{c} / \mathbf{s})\end{array}$ & $\begin{array}{c}\text { Sensitivity (c/s } \\
\text { per n/s) }\end{array}$ \\
\hline $318-356$ & Unmoderated & 3 & 120 & 337905 & 2816 & $5.59 \mathrm{E}-06$ \\
\hline $318-356$ & Unmoderated & 2 & 120 & 332802 & 2773 & $5.51 \mathrm{E}-06$ \\
\hline $318-356$ & Unmoderated & 1 & 120 & 346865 & 2891 & $5.74 \mathrm{E}-06$ \\
\hline $318-356$ & $\mathrm{D}_{2} \mathrm{O}$ Moderated & 1 & 120 & 239791 & 1998 & $3.97 \mathrm{E}-06$ \\
\hline $318-356$ & $\mathrm{D}_{2} \mathrm{O}$ Moderated & 2 & 120 & 226008 & 1883 & $3.74 \mathrm{E}-06$ \\
\hline $318-356$ & $\mathrm{D}_{2} \mathrm{O}$ Moderated & 3 & 120 & 232936 & 1941 & $3.85 \mathrm{E}-06$ \\
\hline $318-016$ & Unmoderated. & 1 & 1003 & 10188 & 10.161 & $5.60 \mathrm{E}-06$ \\
\hline $318-016$ & $\mathrm{D}_{2} \mathrm{O}$ Moderated & 1 & 1026 & 6634 & 6.463 & $3.56 \mathrm{E}-06$ \\
\hline
\end{tabular}

The sensitivity values in Table 3.4 are generally higher than those shown in Table 3.3, indicating that the outer pipe is effective in improving the responses of the detectors, since it provides more neutron moderation than was available from the polyethylene moderator block alone. 


\subsection{Modeling Detector Responses in the 318 Building Low Scatter Room}

The computer code MCNP (Briesmeister 2000) was used to model the responses of the pod to neutrons in a variety of exposure situations. The calibration measurements determined an input parameter that effectively defines the detector sensitivity, and since this sensitivity factor is tied to the Low Scatter Room irradiations, it provides an effective calibration for the MCNP models.

The effort to model the LSR irradiations created a traceability between the calibration irradiations and the hot cell measurement interpretation. The computer code MCNP was used to mathematically model the responses of the detectors. MCNP is a radiation transport computer code that is widely used to model a variety of irradiation conditions. MCNP models were used to interpret the responses of the detectors inside the hot cells and determine the quantity of TRU nuclides in the cell.

MCNP uses a Monte Carlo method for modeling radiation transport, tracking one emitted neutron at a time. Each neutron is allowed to interact with the materials it encounters, changing direction and energy through scattering reactions, or ending its transport when absorbed. In a Monte Carlo simulation, a large number of particles are tracked - these cases typically tracked millions of particles. Larger numbers lead to better modeling statistics, and these simulations were performed with sufficient particles to bring the simulation uncertainties below $2 \%$.

\subsection{Room Geometry}

The LSR was modeled as a simple hollow rectangular box, with floor, walls and ceilings all composed of 3 -ft-thick concrete. This model simplifies the actual room configuration, but adequately models the room return of neutrons to the irradiation position. The interior dimensions of the box were $1000 \mathrm{~cm}$ high ( $\mathrm{z}$ dimension), $1350 \mathrm{~cm}$ long ( $\mathrm{y}$ dimension), and $900 \mathrm{~cm}$ wide ( $\mathrm{x}$ dimension). The source was placed in the center vertically, in the center with respect to the $\mathrm{x}$ dimension, and in the $\mathrm{y}$ dimension, it was placed $500 \mathrm{~cm}$ from one wall and $850 \mathrm{~cm}$ from the other. The irradiation position was placed $100 \mathrm{~cm}$ from the source along the $\mathrm{y}$-axis, $400 \mathrm{~cm}$ from the near wall, but centered in the $\mathrm{x}$ - and z-dimensions. This matches the measurement position used during the calibration exposures. Figure 4.1 shows the LSR room geometry. 


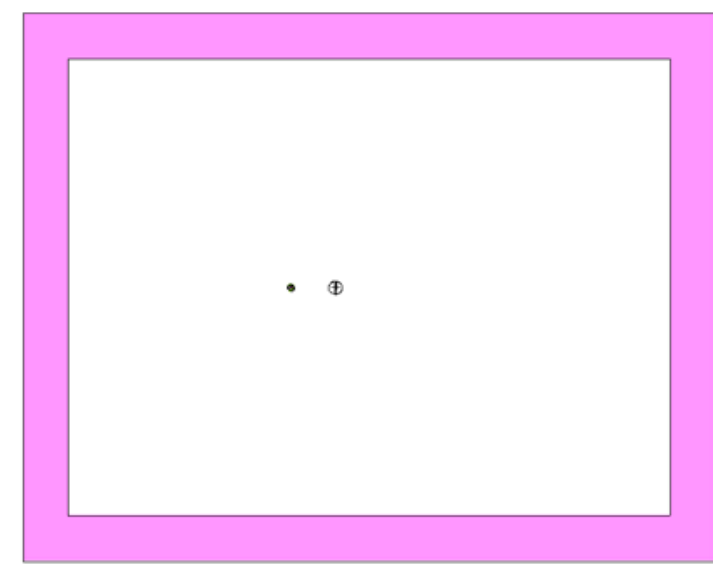

Figure 4.1. Model of the LSR showing the $\mathrm{z}$ (vertical) and $\mathrm{y}$ (horizontal) dimensions.

\subsection{Source Model}

A fairly detailed model of the source was used, including an aluminum rabbit capsule containing californium oxysulfate powder and air, and an aluminum-walled pipe. The dimensions of the encapsulation and piping were taken from design drawings and measurements. (See Figures 4.2 and 4.3.)

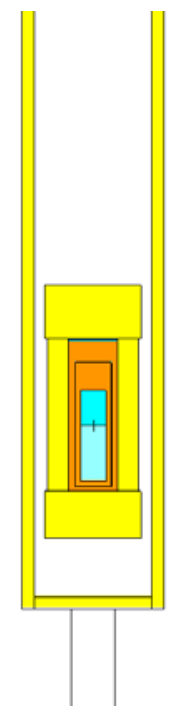

Figure 4.2. Source capsule inside pipe.

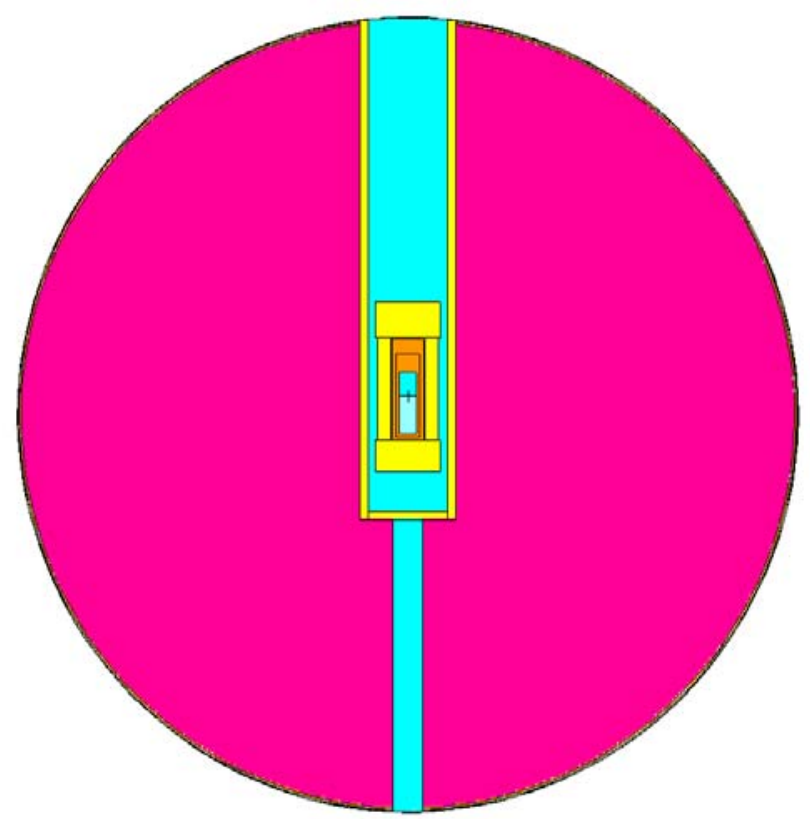

Figure 4.3. $\quad \mathrm{D}_{2} \mathrm{O}$ moderator surrounding neutron source.

The neutron emission rate for the neutron source was $5.16 \times 10^{8} \mathrm{n} / \mathrm{s}$, matching the strength of source 318-356 on June 11, 2002, which is the day that initial tests were performed in the LSR. 


\subsection{Pod Model}

The pod was modeled with simple cylinders. Dimensions of the model were taken from design drawings, detector vendor diagrams, and measurements on the pod itself. Figure 4.4 shows the model of the pipe wall, pod, and detector. Note in Figure 4.4 that details such as cables were omitted from the model. The omitted items were assumed to have no impact on the neutron transport inside the pod.

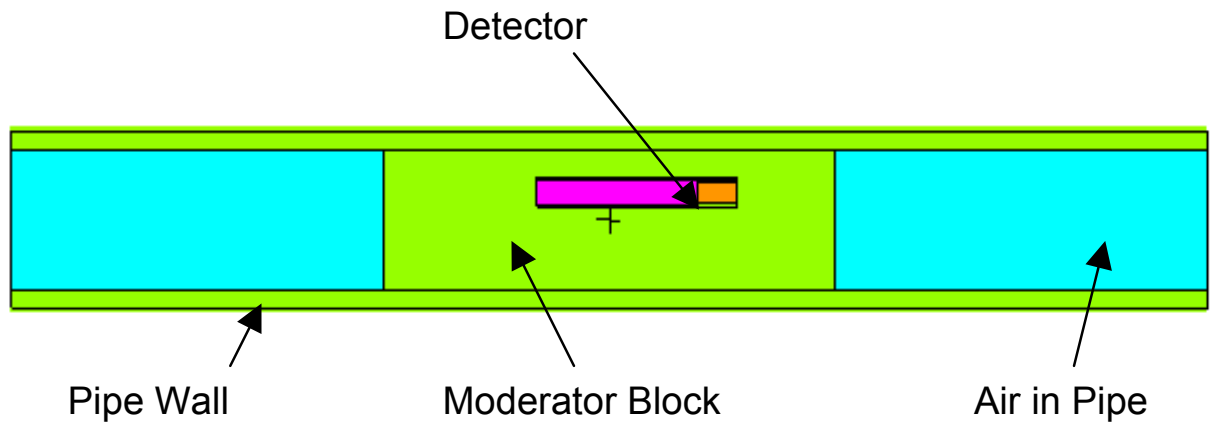

Figure 4.4. Model of the pipe wall, moderator block, and detector.

\subsection{Tallies}

The method of obtaining results from the model calculation involved the use of "tallies," and MCNP provides a number of options for tallying results. For this calculation, a very thin region was modeled on the inside of each detector tube to simulate the uranium coating. The region was modeled as uranium oxide, with an enrichment of $93 \%{ }^{235} \mathrm{U}$, and a total mass of uranium in the region of $0.139 \mathrm{~g}$. Neutrons creating fission events in this region were tallied as an estimate of the detector count rate, since neutron counts in a fission chamber are initiated by the fission events in the uranium coating. The fission tallies in each detector are modified by a conversion constant, which can be used to determine the detector response (the number of counts that are recorded for each fission event). This conversion constant was determined by a test irradiation performed in the LSR with the detectors inside the moderator block, but not inside the pipe, and the pod exposed to neutrons from the unmoderated source 318-356. This conversion constant, 0.00133, was used for all subsequent MCNP models.

\subsection{MCNP Results}

Four configurations were used for these calculations:

- Unmoderated ${ }^{252} \mathrm{Cf}$ source $318-356$, no pipe around the pod

- $\mathrm{D}_{2} \mathrm{O}$-moderated ${ }^{252} \mathrm{Cf}$ source $318-356$, no pipe around the pod

- Unmoderated ${ }^{252} \mathrm{Cf}$ source $318-356$, with the pod inside the pipe

- $\mathrm{D}_{2} \mathrm{O}$-moderated ${ }^{252} \mathrm{Cf}$ source $318-356$, with the pod inside the pipe. 
The modeled count rates are shown in Table 4.1.

Table 4.1. Count rates modeled by MCNP.

\begin{tabular}{||l|l|c|c|c||}
\hline $\begin{array}{c}\text { Pod / Pipe } \\
\text { Configuration }\end{array}$ & $\begin{array}{c}\text { Source } \\
\text { Configuration }\end{array}$ & $\begin{array}{c}\text { Modeled } \\
\text { Count Rate }\end{array}$ & $\begin{array}{c}\mathbf{3 1 8 - 3 5 6} \\
\mathbf{7 / 1 6 / 0 2}(\mathbf{c} / \mathbf{s})\end{array}$ & $\begin{array}{c}\mathbf{3 1 8 - 0 1 6} \\
\mathbf{7 / 1 6 / 0 2}(\mathbf{c} / \mathbf{s})\end{array}$ \\
\hline No Pipe & Unmoderated & 2210 & 2157 & 7.767 \\
\hline No Pipe & $\mathrm{D}_{2}$ O-moderated & 2233 & 2179 & 7.847 \\
\hline Pod in Pipe & Unmoderated & 2965 & 2893 & 10.419 \\
\hline Pod in Pipe & $\mathrm{D}_{2} \mathrm{O}$-moderated & 2087 & 2037 & 7.334 \\
\hline
\end{tabular}

Note that the count rates produced by the four MCNP runs were applicable to the source emission rate on June 11, 2002, but the calibration exposures were performed a month later on July 16, 2002. Thus the modeled count rates were scaled by the changes in source emission rates for the two dates to allow a comparison with measured values. The modeled count rates compare well to the measured count rates for source 318-356.

\subsection{Comparison of Measured and Modeled Count Rates}

A number of measurements were made with the pod and pipe in the LSR, with both neutron sources, and in both moderated and unmoderated source configurations. In several cases, configurations were repeated. A total of 22 measurements were made on July 16 with all three detectors activated. All of these had the pod positioned so that the active center of the pod was $100 \mathrm{~cm}$ from the source. These measurements were compared to the modeled count rates from Table 4.1, and the comparisons are presented in Table 4.2. Table 4.2 indicates excellent agreement between the measured and modeled values. 
Table 4.2. Comparison of measurements to modeled count rates.

\begin{tabular}{|c|c|c|c|c|c|c|c|c|}
\hline $\begin{array}{c}\text { Pod } \\
\text { Configuration } \\
\end{array}$ & $\begin{array}{c}\text { Pod } \\
\text { Orientation } \\
\end{array}$ & $\begin{array}{c}\text { Neutron } \\
\text { Source }\end{array}$ & $\begin{array}{c}\text { Source } \\
\text { Configuration } \\
\end{array}$ & $\begin{array}{l}\text { Total Neutron } \\
\text { Counts }\end{array}$ & $\begin{array}{c}\text { Live } \\
\text { Time (s) } \\
\end{array}$ & $\begin{array}{c}\text { Measured } \\
\text { Count Rate } \\
(\mathrm{c} / \mathrm{s})\end{array}$ & $\begin{array}{c}\text { Modeled } \\
\text { Count Rate } \\
(\mathrm{c} / \mathrm{s})\end{array}$ & $\begin{array}{l}\text { Ratio Model/ } \\
\text { Measurement }\end{array}$ \\
\hline No Pipe & 1 & $318-016$ & Unmoderated & 7076 & 1000 & 7.076 & 7.767 & 1.098 \\
\hline No Pipe & 2 & $318-016$ & Unmoderated & 6,870 & 1000 & 6.870 & 7.767 & 1.131 \\
\hline No Pipe & 3 & $318-016$ & Unmoderated & 4,955 & 717 & 6.913 & 7.767 & 1.124 \\
\hline No Pipe & 2 & $318-016$ & Unmoderated & 39,209 & 5150 & 7.613 & 7.767 & 1.020 \\
\hline No Pipe & 1 & $318-356$ & Unmoderated & 257,794 & 120 & 2148 & 2157 & 1.004 \\
\hline No Pipe & 2 & $318-356$ & Unmoderated & 256,843 & 120 & 2140 & 2157 & 1.008 \\
\hline No Pipe & 2 & $318-356$ & Unmoderated & 199,140 & 100 & 1991 & 2157 & 1.083 \\
\hline No Pipe & 3 & $318-356$ & Unmoderated & 254,175 & 120 & 2118 & 2157 & 1.018 \\
\hline No Pipe & 3 & $318-356$ & Unmoderated & 198,560 & 100 & 1986 & 2157 & 1.086 \\
\hline No Pipe & 3 & $318-356$ & $\mathrm{D}_{2} \mathrm{O}$-Moderated & 246,794 & 120 & 2057 & 2179 & 1.060 \\
\hline No Pipe & 3 & $318-356$ & $\mathrm{D}_{2} \mathrm{O}$-Moderated & 254,674 & 120 & 2122 & 2179 & 1.027 \\
\hline No Pipe & 1 & $318-356$ & $\mathrm{D}_{2} \mathrm{O}$-Moderated & 194,145 & 100 & 1941 & 2179 & 1.122 \\
\hline No Pipe & 2 & $318-356$ & $\mathrm{D}_{2} \mathrm{O}$-Moderated & 192,499 & 100 & 1925 & 2179 & 1.132 \\
\hline No Pipe & 3 & $318-356$ & $\mathrm{D}_{2} \mathrm{O}$-Moderated & 198,558 & 100 & 1986 & 2179 & 1.097 \\
\hline Pod in Pipe & 3 & $318-356$ & Unmoderated & 337,905 & 120 & 2816 & 2893 & 1.028 \\
\hline Pod in Pipe & 2 & $318-356$ & Unmoderated & 332,802 & 120 & 2773 & 2893 & 1.043 \\
\hline Pod in Pipe & 1 & $318-356$ & Unmoderated & 346,865 & 120 & 2891 & 2893 & 1.001 \\
\hline Pod in Pipe & 1 & $318-016$ & Unmoderated & 10,188 & 1003 & 10.161 & 10.419 & 1.025 \\
\hline Pod in Pipe & 1 & $318-356$ & $\mathrm{D}_{2} \mathrm{O}$-Moderated & 239,791 & 120 & 1998 & 2037 & 1.019 \\
\hline Pod in Pipe & 2 & $318-356$ & $\mathrm{D}_{2} \mathrm{O}$-Moderated & 226,008 & 120 & 1883 & 2037 & 1.081 \\
\hline Pod in Pipe & 3 & $318-356$ & $\mathrm{D}_{2} \mathrm{O}$-Moderated & 232,936 & 120 & 1941 & 2037 & 1.049 \\
\hline Pod in Pipe & 1 & $318-016$ & $\mathrm{D}_{2} \mathrm{O}$-Moderated & 6,634 & 1026 & 6.463 & 7.334 & 1.135 \\
\hline
\end{tabular}




\subsection{Measurements in the 327 Building $G$ and $H$ Hot Cells}

Figure 5.1 shows the layout of the hot cells in the west end of the 327 Building Canyon.

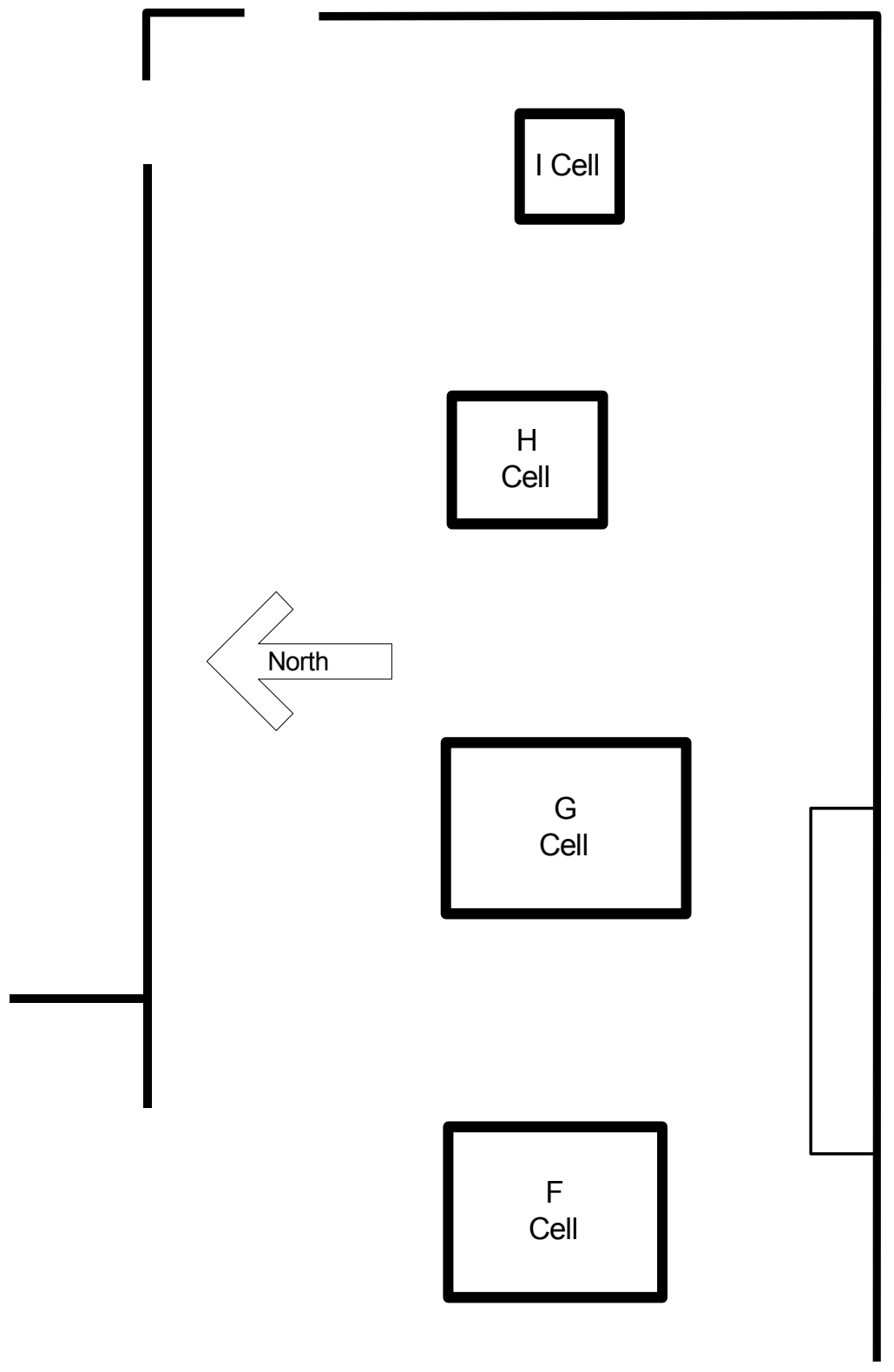

Figure 5.1. Hot Cells in the west end of the 327 Building Canyon. 


\subsection{Measurements in $\mathbf{G}$ and $\mathrm{H}$ Cells}

For both $\mathrm{G}$ and $\mathrm{H}$ Cells, the pod was inserted through a port in the west wall. The west wall of each cell contains a rectangular array of ports, which normally contain steel plugs. When a port was designated for access, the steel plug would be removed by workers using procedures to limit the chances of spreading contamination. After a port's plug was removed, a steel collar was inserted into the port. The steel collar was attached to a thin plastic sleeve that extended into the cell and provided contamination protection for the traverse pipe. The plastic traverse pipe was fed into the cell through the steel collar. The pod could then be inserted inside the plastic pipe.

Figure 5.2 shows the traverse pipe being inserted into G Cell through a port in the west wall, and Figure 5.3 shows the handle of the pod extending from the end of the pipe.

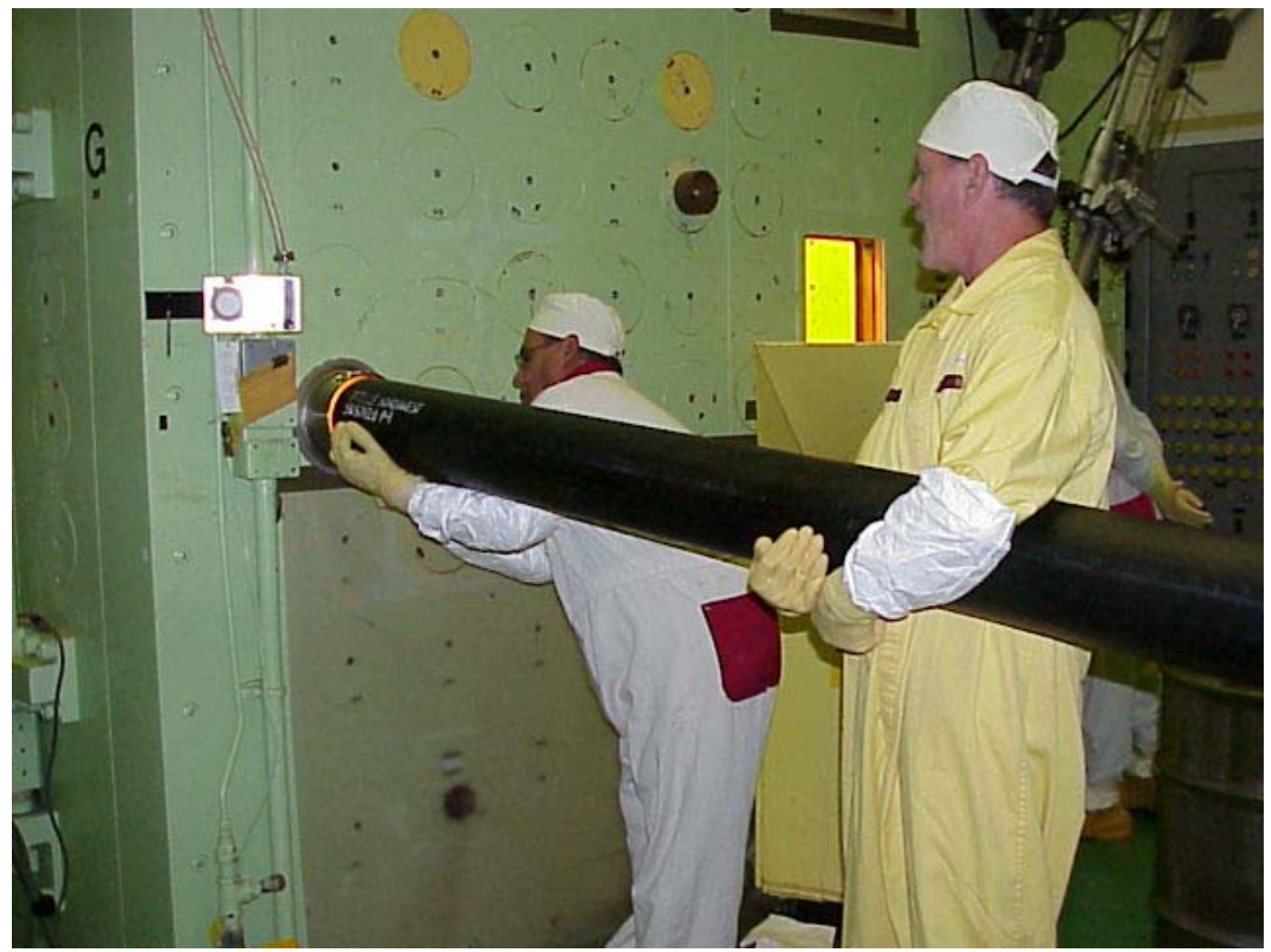

Figure 5.2. Workers inserting the traverse pipe into a port in G Cell. 


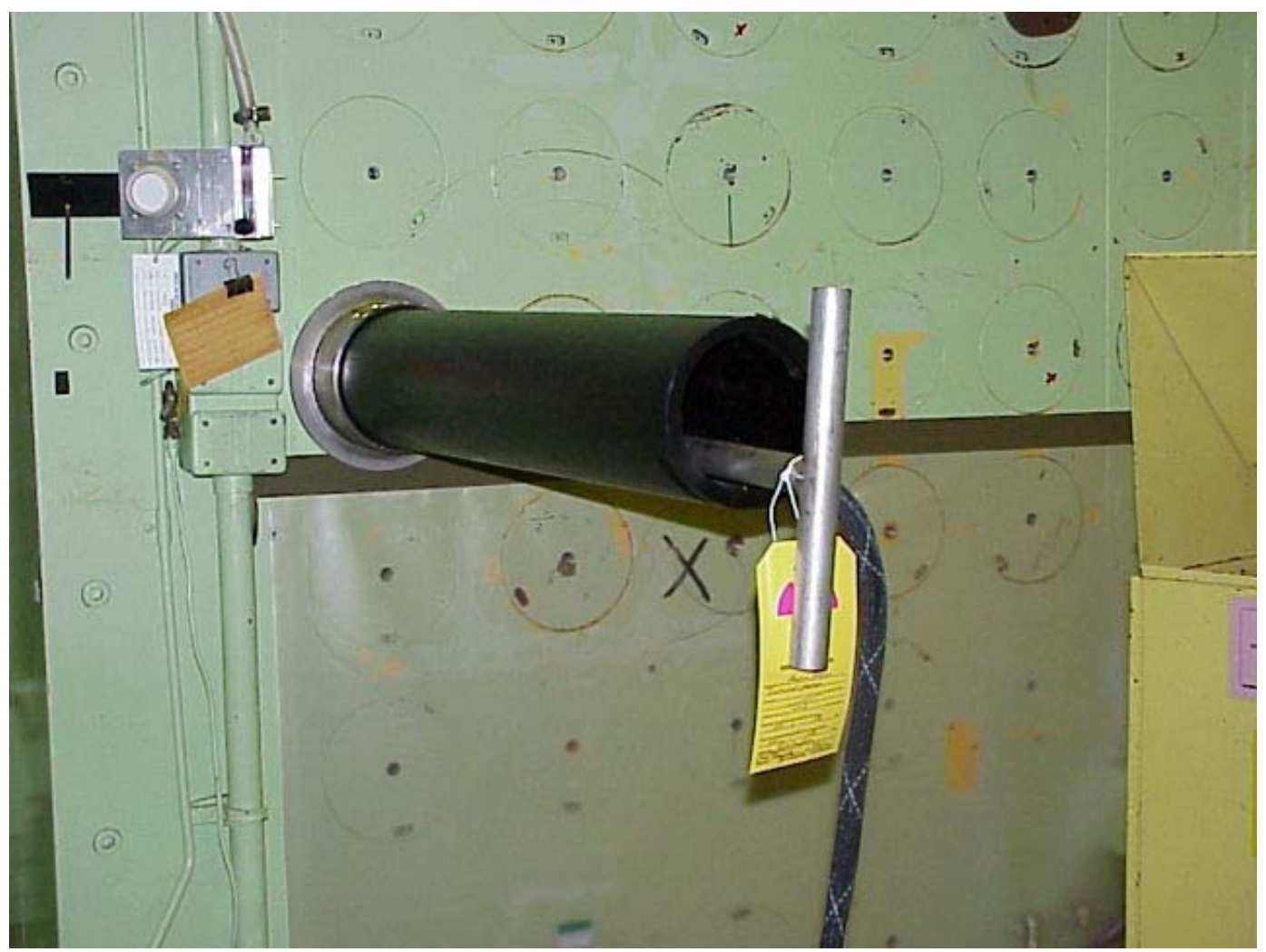

Figure 5.3. Handle of pod extending from traverse pipe in a G Cell port. The measurement position in this picture has the pod fully inserted in the pipe.

The pod's position in a cell was recorded using the row and column of the port in the west wall's array of ports, and depth of insertion of the pod. "Row" defined the vertical location, "column" defined the northsouth location, and "insertion" defined the east-west location. Row, column, and insertion were recorded on the data sheets. For position identification on the data sheets, the row refers to a horizontal line of ports in the west wall of the cell; row \#1 is the highest one on the wall, and the row number increases as the height above the floor decreases. All measurements in both cells were made in row \#4. The column refers to a vertical line of ports. Column $\# 1$ is the line of ports nearest to the north wall of the cell. G Cell contained 12 columns of ports, and H Cell contained 6 columns.

The pod's depth of "insertion" defined the pod's position on an east-west line in the cell. Insertion was defined as the distance between the outside surface of the cell's wall and the active center of the detector pod.

For each pod position, a multichannel analyzer (MCA) spectrum was collected. Since count rates were very low, these counts were recorded for at least 15 minutes to collect a meaningful number of neutron counts. Even with the long count times, the number of counts collected in G and H Cells were very low: never above 35 counts for a 15 -minute count time. The counting statistics uncertainty for 35 counts is \pm 6 counts, corresponding to a $17 \%$ uncertainty. 
For each recorded MCA spectrum, a discriminator was set at an MCA channel number selected during a source check measurement (see Section 5.4 for a discussion of source checks). The total number of neutron counts registering above the discriminator channel was recorded on the data sheet, where it was used for initial estimates of neutron count rate. Also recorded on the data sheets were the log number, the measurement location, the discriminator channel (called "ROI low ch \#"), the count time (the "live time" from the MCA), the file name where the spectrum was stored, and any comments.

The evaluated neutron count rates were found by fitting the MCA data to obtain a good separation between detector-background and neutron counts; dividing by the count time to get a "raw" count rate; then subtracting off background neutron count rates to get a net count rate corresponding to neutrons emitted from material inside the cell. The remaining sections in this chapter document the method of finding these values.

\subsection{Determination of Measured Neutron Count Rates}

The MCA spectrum for a pod count included pulses that resulted from the following sources:

- neutrons entering the fission chamber (detector), creating fissions in the uranium lining of the detector, and producing high-energy-deposition pulses

- background alphas emitted by uranium in the detector lining

- background gammas, either from outside the detector or from the uranium lining

- miscellaneous background electronic noise.

The pulses generated by the three sources of detector background are much smaller than the pulses generated by neutron-induced fission, so the analysis of a fission chamber spectrum requires discrimination between the two types of pulses. The method of setting a region of interest (ROI) on a spectrum and summing the counts in the ROI is an efficient method that can be performed on the MCA and gives immediate results, but it has the disadvantage of including some background events that occur above the discrimination point and rejecting some neutron events that occur below the rejection point. A better method is to perform a curve fit of the background portion of the spectrum, extrapolate a trend line to zero, and subtract these counts from the raw spectrum to obtain the neutron events. The curve fit is best performed when the data is plotted on a logarithmic scale on the vertical axis (which is identical to fitting a straight line to the base-10 log of the counts per channel).

Figure 5.4 illustrates the analysis method used for discriminating between background and neutron events, using a spectrum collected in the LSR, with the counts per channel divided by the live time to get a count rate per channel. 


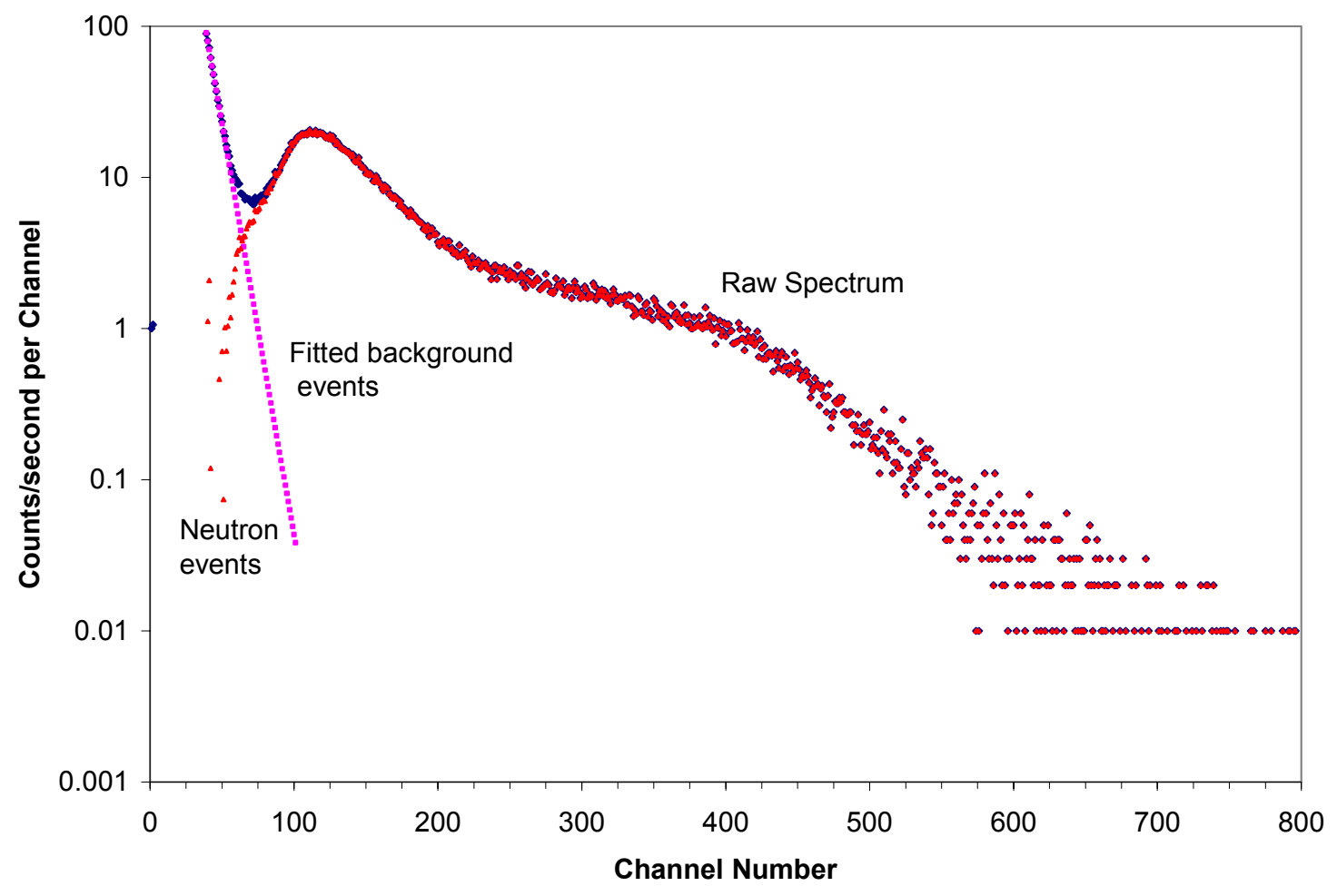

Figure 5.4. Discriminating between background and neutron events.

Figure 5.4 shows that some neutron events lie below the discriminator channel that would be used for an ROI, and some background counts lie above it. The first step in the analysis is fitting a straight line on the semi-logarithmic plot to the background events, to obtain background count rate per channel in all the lower channels of the spectrum (illustrated by the points in a straight line labeled "fitted background counts"). This background value for each channel can then be subtracted from the raw count rate for each channel to obtain the fitted neutron count rate. For the lowest channels, this fitted neutron count rate will be zero, and for the highest channels, it will be equal to the raw spectrum values, but for the channels in the vicinity of the discriminator, it is important to perform the fitted background subtraction. The total neutron count rate can be found by summing all the net neutron count rates for all channels. This value is called the "raw fitted neutron" count rate in the remainder of this report. Note that this background subtraction refers only to non-neutron counts generated inside the detector tube, and is a separate problem from subtracting the background neutron counts that are produced by neutrons not originating in TRU.

\subsection{Background Measurements}

The neutron counts recorded by the neutron pod during a measurement inside the cell could come from either of two primary sources:

- neutrons emitted by radioactive material (TRU) inside the cell

- neutrons originating outside the cell's interior (background neutrons). 
The TRU characterization requires that only neutrons emitted by TRU inside the hot cell be considered, so a distinction must be made between neutrons originating from material inside the cell and those originating from elsewhere. The background component must therefore be identified and subtracted. Background neutron count rates were determined by positioning the detector in the 327 Canyon Building, near the hot cells but not too close to one that may contain TRU. However, while this is a standard method of measuring background radiation, it does not completely account for the true nature of background neutrons in the 327 Building.

Identifying background neutrons in a hot cell is complex because they come from multiple sources. Some neutrons are naturally present in the environment, primarily from cosmic radiation interacting in the atmosphere, and thus originate outside the 327 Building. However, there is also a neutron source from the interaction of cosmic radiation with atoms in the iron cell walls (Haggard et al. 1998). In the case of neutrons originating outside of the building, the neutron flux would be attenuated as it was transported through the iron cell walls. However, for neutrons generated in the iron cell walls, the background neutron count rate would actually increase inside the cell because the measurement point would be totally surrounded by massive quantities of iron.

An accurate measurement of neutron background would require placing the neutron pod inside an assembly containing many tons of iron, with an assurance that the iron contained no TRU or other neutron emitters. The count rate would vary from day to day as cosmic radiation levels fluctuated, so these measurements would need to be performed on every measurement day. Since this approach was impractical for the $\mathrm{G}$ and $\mathrm{H}$ Cell measurements, it was assumed that the background measurements performed in the canyon near the hot cells were reasonable estimates of the background count rates in the cells.

Background neutron count rates were measured by positioning the pod outside the cell and counting for long periods of time. Background counts were made in a number of locations around $\mathrm{G}$ and $\mathrm{H}$ Cells, and some locations were counted more than once. Each in-cell count was matched with an appropriate background measurement (or the average of two or three); chosen for a nearby location and measured on the same day. 
Table 5.1 gives the results of the background measurements used to adjust the measured count rates inside the hot cells.

Table 5.1. Background measurements near hot cells.

\begin{tabular}{|c|c|c|c|c|c|}
\hline $\log \#$ & Date & Location & $\begin{array}{c}\text { Count } \\
\text { Time(s) }\end{array}$ & $\begin{array}{l}\text { Background } \\
\text { Count Rate } \\
(\mathrm{c} / \mathrm{s})\end{array}$ & $\begin{array}{c}\text { In-Cell Measurements } \\
\text { using this } \\
\text { Background (Log \#) }\end{array}$ \\
\hline 201 & $10 / 28 / 02$ & Near west wall of I Cell & 4590 & 0.0088 & $204-208$ \\
\hline $209 a$ & $10 / 28-29 / 02$ & Near west wall of I Cell & 60,244 & 0.0117 & \\
\hline 216 & $10 / 29 / 02$ & Near west wall of I Cell & 7443 & 0.0180 & \\
\hline \multicolumn{3}{|c|}{ Average of $209 a$ and 216} & 67,687 & 0.0124 & $\begin{array}{l}212-215 \\
219-223\end{array}$ \\
\hline 224 & $11 / 4 / 02$ & Between F and G Cells & 100,000 & 0.0172 & \\
\hline 226 & $11 / 4 / 02$ & Between H and I Cells & 1220 & 0.0137 & \\
\hline 229 & $11 / 4-5 / 02$ & $\begin{array}{l}\text { Near canyon south } \\
\text { wall, by I Cell }\end{array}$ & 58,531 & 0.0116 & \\
\hline 231 & $11 / 5 / 02$ & $\begin{array}{l}\text { Near canyon south } \\
\text { wall, by I Cell }\end{array}$ & 420 & 0.0180 & \\
\hline 236 & $11 / 5 / 02$ & $\begin{array}{l}\text { Near south canyon } \\
\text { wall, by G Cell }\end{array}$ & 1017 & 0.0152 & \\
\hline 237 & $11 / 5 / 02$ & Between $\mathrm{G}$ and H Cells & 6906 & 0.0141 & \\
\hline \multicolumn{3}{|c|}{ Average of 236 and 237} & 7923 & 0.0143 & $\begin{array}{c}227,228 \\
232-235\end{array}$ \\
\hline \multicolumn{3}{|c|}{ Average of 226, 229, 231, 237} & 67,077 & 0.0119 & $239-244$ \\
\hline
\end{tabular}

\subsection{Evaluated Neutron Count Rates}

The fitted raw neutron counts for each measurement were found using the technique presented in Section 5.2. The background neutron portion was then subtracted from the raw neutron count rate to obtain the net neutron count rate, and this was the value directly used to determine TRU quantity. 
Table 5.2 presents the evaluated neutron count rates inside the $\mathrm{G}$ and $\mathrm{H}$ Cells.

Table 5.2. Evaluated neutron count rates inside $\mathrm{G}$ and $\mathrm{H}$ Cells.

\begin{tabular}{|c|c|c|c|c|c|c|}
\hline Cell & Row / Col & $\begin{array}{c}\text { Distance } \\
\text { From Inside } \\
\text { East Wall } \\
\text { (in.) }\end{array}$ & $\begin{array}{c}\text { Fitted Raw } \\
\text { Neutron } \\
\text { Count Rate c/s }\end{array}$ & \begin{tabular}{|c|} 
Net Neutron \\
Count Rate c/s
\end{tabular} & $\begin{array}{c}\text { Net Neutron } \\
\text { Uncertainty } \\
\text { c/s }\end{array}$ & NDA Log \# \\
\hline G & $\mathrm{r} 4 / \mathrm{c} 1$ & 56 & 0.0160 & 0.0018 & 0.0051 & 228 \\
\hline G & $\mathrm{r} 4 / \mathrm{c} 1$ & 26 & 0.0205 & 0.0063 & 0.0046 & 227 \\
\hline G & $\mathrm{r} 4 / \mathrm{c} 5$ & 66.5 & 0.0103 & 0.0016 & 0.0037 & 207 \\
\hline G & $\mathrm{r} 4 / \mathrm{c} 5$ & 48.5 & 0.0068 & -0.0020 & 0.0030 & 206 \\
\hline G & $\mathrm{r} 4 / \mathrm{c} 5$ & 34.25 & 0.0109 & 0.0021 & 0.0038 & 205 \\
\hline G & $\mathrm{r} 4 / \mathrm{c} 5$ & 11.5 & 0.0098 & 0.0011 & 0.0035 & 204 \\
\hline G & $\mathrm{r} 4$ / c9 & 34.5 & 0.0163 & 0.0075 & 0.0044 & 208 \\
\hline G & $\mathrm{r} 4 / \mathrm{c} 12$ & 66.5 & 0.0196 & 0.0053 & 0.0044 & 235 \\
\hline G & $\mathrm{r} 4$ / c12 & 49.5 & 0.0305 & 0.0162 & 0.0059 & 234 \\
\hline G & $\mathrm{r} 4 / \mathrm{c} 12$ & 31.5 & 0.0201 & 0.0058 & 0.0049 & 233 \\
\hline G & $\mathrm{r} 4 / \mathrm{c} 12$ & 11.6 & 0.0184 & 0.0041 & 0.0044 & 232 \\
\hline G & $\mathrm{r} 4$ / c12 & 66.9 & $0.0290^{\text {(a) }}$ & $0.0166^{(\mathrm{a})}$ & 0.0052 & 215 \\
\hline G & $\mathrm{r} 4 / \mathrm{c} 12$ & 58.9 & $0.0145^{(\mathrm{a})}$ & $0.0021^{(a)}$ & 0.0038 & 214 \\
\hline G & $\mathrm{r} 4$ / c12 & 39.9 & $0.0315^{(\mathrm{a})}$ & $0.0191^{(\mathrm{a})}$ & 0.0051 & 213 \\
\hline $\mathrm{G}$ & r4 / c12 & 21.1 & $0.0152^{(a)}$ & $0.0028^{(a)}$ & 0.0040 & 212 \\
\hline $\mathrm{H}$ & $\mathrm{r} 4 / \mathrm{c} 1$ & 45.6 & $0.0240^{\text {(a) }}$ & $0.0116^{(\mathrm{a})}$ & 0.0058 & 221 \\
\hline $\mathrm{H}$ & $\mathrm{r} 4 / \mathrm{c} 1$ & 45.5 & 0.0196 & 0.0076 & 0.0043 & 244 \\
\hline $\mathrm{H}$ & $\mathrm{r} 4 / \mathrm{c} 1$ & 28.7 & $0.0254^{(\mathrm{a})}$ & $0.0130^{(\mathrm{a})}$ & 0.0062 & 220 \\
\hline $\mathrm{H}$ & $\mathrm{r} 4 / \mathrm{c} 1$ & 10.1 & 0.0205 & 0.0086 & 0.0050 & 243 \\
\hline $\mathrm{H}$ & $\mathrm{r} 4 / \mathrm{c} 1$ & 9.56 & $0.0243^{(\mathrm{a})}$ & $0.0119^{(\mathrm{a})}$ & 0.0059 & 219 \\
\hline $\mathrm{H}$ & $\mathrm{r} 4 / \mathrm{c} 3$ & 38 & $0.0225^{\text {(a) }}$ & $0.0101^{\text {(a) }}$ & 0.0058 & 223 \\
\hline $\mathrm{H}$ & $\mathrm{r} 4 / \mathrm{c} 3$ & 28.5 & 0.0183 & 0.0064 & 0.0042 & 242 \\
\hline $\mathrm{H}$ & $\mathrm{r} 4 / \mathrm{c} 3$ & 19.5 & $0.0369^{(a)}$ & $0.0245^{(\mathrm{a})}$ & 0.0063 & 222 \\
\hline $\mathrm{H}$ & $\mathrm{r} 4$ / c6 & 45.5 & 0.0188 & 0.0069 & 0.0043 & 241 \\
\hline $\mathrm{H}$ & r4 / c6 & 28.5 & 0.0286 & 0.0167 & 0.0055 & 240 \\
\hline $\mathrm{H}$ & r4 / c6 & 10.25 & 0.0148 & 0.0029 & 0.0038 & 239 \\
\hline
\end{tabular}


Table 5.2 shows that all measurements in G Cell were made in row 4, so all pod positions were at the same height. For these positions, the center of the pod was $44 \mathrm{in}$. above the top surface of the cast iron floor, or $15.25 \mathrm{in}$. above the top of the steel tray. Measurements were performed using four different ports in G Cell. The column number of the port indicates the position of the center of the pod in the north-south direction, as shown in Table 5.3.

Table 5.3. North-south positions of measurement locations in $\mathrm{G}$ and $\mathrm{H}$ Cells.

\begin{tabular}{|c|c|c|c|}
\hline \multirow{2}{*}{$\frac{\text { Cell }}{\mathrm{G}}$} & \multirow{2}{*}{$\begin{array}{c}\text { Column } \\
\text { Column } 1\end{array}$} & \multicolumn{2}{|c|}{$\begin{array}{cc}\begin{array}{c}\text { Distance, Inches, from Inside Surface of Wall } \\
\text { North }\end{array} & \text { South } \\
\end{array}$} \\
\hline & & 7 & 117 \\
\hline $\mathrm{G}$ & Column 5 & 47 & 77 \\
\hline $\mathrm{G}$ & Column 9 & 87 & 37 \\
\hline $\mathrm{G}$ & Column 12 & 118 & 6 \\
\hline $\mathrm{H}$ & Column 1 & 7 & 57 \\
\hline $\mathrm{H}$ & Column 3 & 27 & 37 \\
\hline $\mathrm{H}$ & Column 6 & 57 & 7 \\
\hline
\end{tabular}

Measurements in H Cell were also made at a constant height, 45 in. above the top surface of the H Cell cast iron floor, or 6-in. above the top of the steel tray. Three different ports were used for H Cell measurements, and their positions are given in Table 5.3.

Note that for several measurements, the count rates were elevated because a cask containing TRU was placed next to H Cell for a day. While these measurements should not be used for evaluation of the TRU contents in the cell, they were included in this table for completeness.

One net neutron count rate was less than zero, indicating that the background count rate was higher than the measured count rate. While this might seem physically impossible, it is commonly observed in very low count rate measurements where the counting statistics uncertainty is high. Also, a number of net count rates were lower than the associated counting uncertainties, showing that a total absence of TRU in the cell is a possibility.

\subsection{Source Checks}

As a check of proper operation, a "source check" was performed frequently to ensure that the three detectors inside the pod were operating properly. The source check was performed using a small, unmoderated ${ }^{252} \mathrm{Cf}$ source. The source check was performed with the pod inside an outer pipe (either the actual traverse pipe, or a shorter version used only for calibrations). The source was placed against the outside of the polyethylene outer pipe, approximately aligned with the active center of the detectors inside the pod. This positioning was performed without careful measurement, and no care was given to the rotation of the pod inside the pipe. Thus some source check exposures had the source closer to a single detector tube than others, introducing variability into the expected count rate. An MCA spectrum was collected, with sufficient measurement time to collect at least 1000 counts. 
A "control chart" was kept to track the performance of the detector system over time, and was frequently checked by the operator to ensure that no irregularities degraded system performance.

\subsection{Measurement Uncertainties}

Both the in-cell pod measurements and the background measurements had a very low count rate, and this resulted in relatively high uncertainties because the measurement result was based on a small number of events. The counting statistics uncertainty is equal to the square root of the recorded counts, and each measurement's raw neutron count had an uncertainty of $17 \%$ or greater before correction for background, as mentioned in Section 2.1. This uncertainty could have been reduced by longer counting times (giving more recorded events per measurement), but operational considerations made longer count times unreasonable.

The counting uncertainties for the evaluated neutron counts inside the cell are listed in Table 5.2. In $\mathrm{G}$ Cell, the uncertainties were often larger than the measured value. In $\mathrm{H}$ Cell, most of the uncertainties are in the range of 50 to $65 \%$, and one has an uncertainty of $131 \%$.

Other uncertainties that may exist in the measurement, such as positioning, or subtracting detector background, are far smaller than the counting statistics uncertainty, so the values listed in Table 5.2 provide a good estimate of each measurement's uncertainty. 


\subsection{Modeling Detector Responses in the 327 Building Hot Cells}

The neutron counts detected in the hot cell were insufficient by themselves to estimate the quantity of TRU in a cell, since the count rate is determined not only by quantity, but also by location of the neutron emitters in the cell. Thus the general strategy for combining the results of hot cell measurements and hot cell modeling to estimate the quantity of TRU in a cell is to examine the measured count rates to determine a spatial pattern, then develop a model with a source distribution that produces the same spatial pattern in the calculated count rates, then adjust the total source strength in the model to make the calculated count rates match the measured count rates. For the TRU characterization of G and H Cells, this process was simplified because all of the measured count rates were so close to zero that the measurement uncertainties masked any spatial variation that may have been observable. This section discusses the modeling effort.

\subsection{Modeling G Cell}

G Cell was modeled as a simple rectangular box with the dimensions given in Table 6.1.

Table 6.1. Dimensions of G-cell model.

\begin{tabular}{|c|c|c|c||}
\hline Dimension & $\begin{array}{c}\text { Outer Length } \\
\text { (ft-in.) }\end{array}$ & $\begin{array}{c}\text { Inner Length } \\
\text { (ft-in.) }\end{array}$ & Wall Thickness (in.) \\
\hline East - West & $8 \mathrm{ft} 0 \mathrm{in}$. & $6 \mathrm{ft} 5 \mathrm{in}$. & $9.5 \mathrm{in}$. \\
\hline North - South & $12 \mathrm{ft} 0 \mathrm{in}$. & $10 \mathrm{ft} 4 \mathrm{in}$. & $10 \mathrm{in.}$ \\
\hline Vertical & $9 \mathrm{ft} 8 \mathrm{in}$. & $8 \mathrm{ft} 4.5 \mathrm{in}$. & $\begin{array}{c}\text { Ceiling: } 9.5 \mathrm{in} . \\
\text { Floor: } 6 \mathrm{in.}\end{array}$ \\
\hline
\end{tabular}

The dimensions were taken from engineering drawings of the cell. Features of the cell such as portholes, windows and doors were omitted from the model because they would have a trivial effect on the transport of neutrons. The wall material used a composition appropriate for Meehanite Ductile Iron Grade $60-40-18$, consisting of $94 \%$ (by weight) iron, $3.42 \%$ carbon, $2.5 \%$ silicon and $0.8 \%$ phosphorus, at a density of $7.2 \mathrm{~g} / \mathrm{cm}^{3}$. The only internal structure included in the G-Cell model was the steel tray, assumed to extend from wall to wall in both east-west and north-south dimensions. The interior volume of the cell was filled with air (except for space occupied by the neutron pod and traverse pipe).

The floor of the canyon was modeled as a concrete slab, 12 in. thick, extending to the limits of the model in all horizontal directions.

The model of the neutron pod included a polyethylene cylinder with internal cavities to accommodate the three fission chamber tubes. A thin coating of highly-enriched uranium was modeled on the inside of the detector tube wall, and the neutron transport calculation tallied the number of neutrons that had fission interactions with the uranium atoms to estimate the response of the detector to a neutron source. An outer pipe was modeled around the pod's polyethylene cylinder to match the traverse pipe. The length of the 
traverse pipe in the model was chosen to be slightly longer than the cylindrical moderator, rather than extending the width of the cell. The omitted part of the traverse pipe would have a negligible contribution to the pod's detector count, but it could interfere with the count at other pod locations modeled in the same calculation. A diagram of the G-cell model, looking north, is given in Figure 6.1.

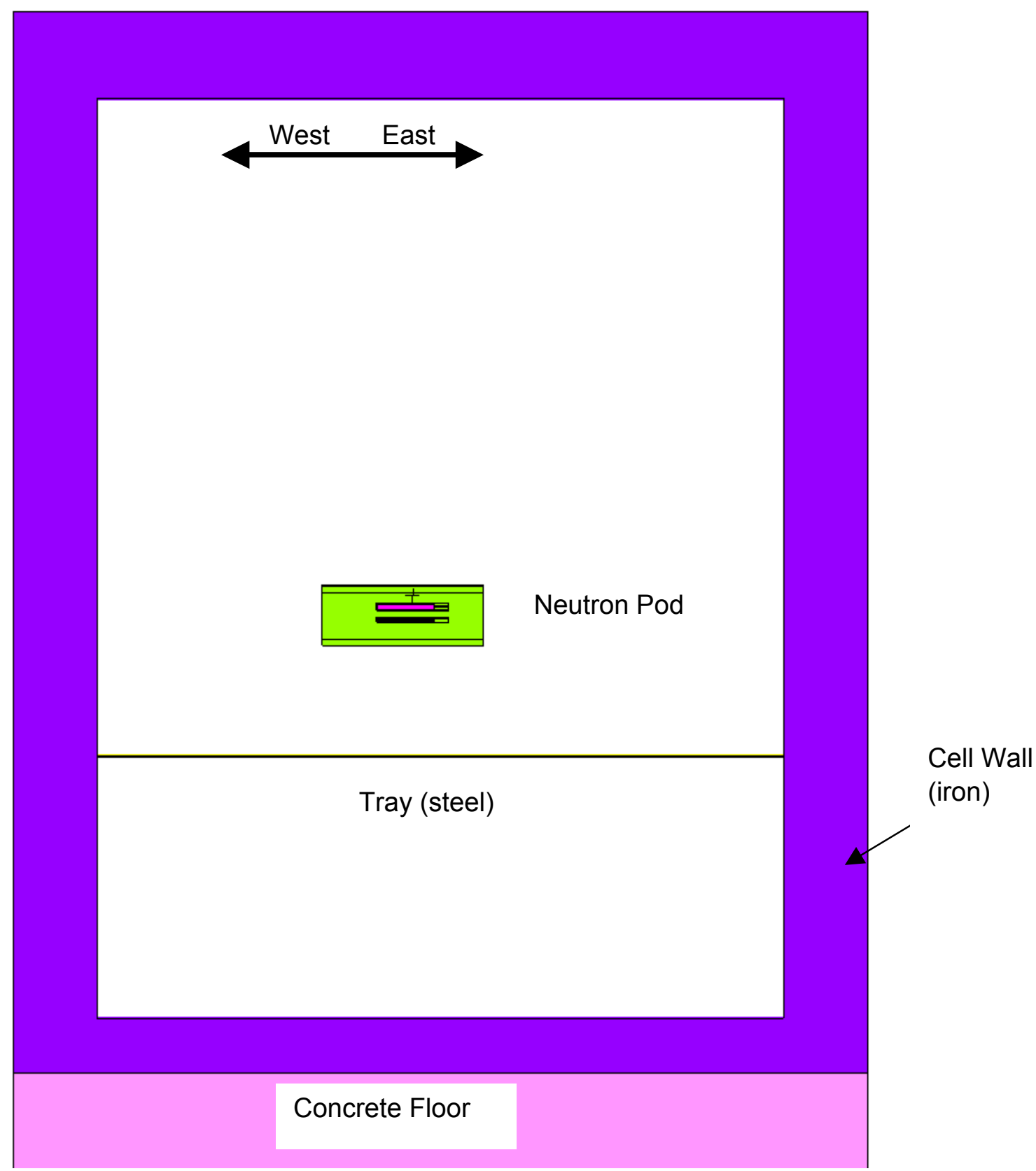

Figure 6.1. Model of G Cell for neutron transport calculation.

Eleven positions for detector pods in G Cell were used in the MCNP calculations, chosen to be representative of most of the measurement positions shown in Table 6.1. It would have been possible to 
place 11 detector pods in the cell for one calculation, and tally the results, and this would have been efficient. However, multiple pods in the cell introduce neutron moderation in the form of polyethylene that was not present during the actual measurement. This additional moderation would have affected the modeled detector responses, particularly for a detector placed very close to another pod. On the other hand, running 11 calculations with only 1 pod in the cell increases the computation time substantially. As a compromise between the two extremes, four MCNP calculations were performed for G Cell, with either two or three pods in the cell for each, and the pods spaced well apart from each other for any one calculation.

\subsection{Modeling H Cell}

The model of H Cell, which is smaller than G Cell, was also based on engineering drawings, using an idealized rectangular shape with no features such as windows or portholes. The steel tray was assumed to extend from wall to wall in both horizontal dimensions, with no openings in the tray. The dimensions for this model's outer walls are given in Table 6.2.

Table 6.2. Dimensions of H-cell model.

\begin{tabular}{||c|c|c|c||}
\hline Dimension & $\begin{array}{c}\text { Outer Length } \\
\text { (ft-in.) }\end{array}$ & $\begin{array}{c}\text { Inner Length } \\
\text { (ft-in.) }\end{array}$ & $\begin{array}{c}\text { Wall Thickness } \\
\text { (in.) }\end{array}$ \\
\hline East - West & $6 \mathrm{ft} 4 \mathrm{in.}$ & $4 \mathrm{ft} 7 \mathrm{in.}$ & $10.5 \mathrm{in.}$ \\
\hline North - South & $7 \mathrm{ft} 1$ in. & $5 \mathrm{ft} 4$ in. & $10.5 \mathrm{in.}$ \\
\hline Vertical & $8 \mathrm{ft} 10$ in. & $7 \mathrm{ft} 5.5$ in. & $\begin{array}{c}\text { Ceiling: } 10.5 \mathrm{in.} \\
\text { Floor: } 6 \text { in. }\end{array}$ \\
\hline
\end{tabular}


Figure 6.2 shows the modeled layout of $\mathrm{H}$ Cell, giving a north-south view.

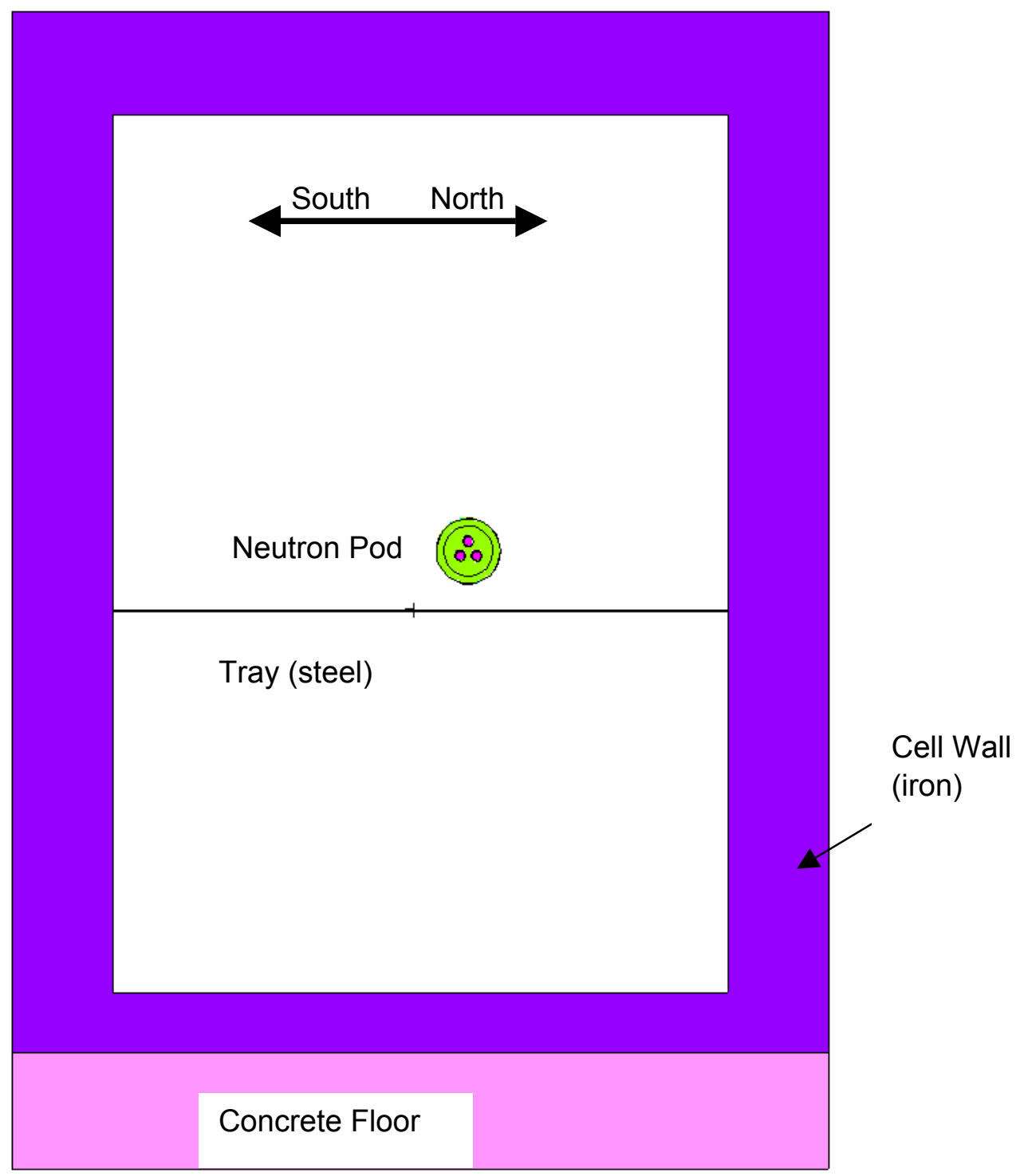

Figure 6.2. Model of H Cell.

Detectors were modeled in nine positions in H Cell, corresponding to three insertion depths for each of three cell ports. Three MCNP calculations were performed, with three pods in each calculation. 


\subsection{Hot Cell Source Terms}

For each cell model, three different source distributions were used. For each case, the model assumed that plutonium oxide powder was spread in a very thin layer over horizontal or vertical surfaces. The model assumed that the plutonium had " $12 \%$ " isotopics, with the isotopic composition shown in Table 6.3. This model assumed that no other TRU isotopes capable of emitting neutrons were present in the cell.

Table 6.3. Isotopic composition of plutonium used in hot cell model.

\begin{tabular}{|c|c|c|}
\hline Isotope & Pu Weight Fraction & $\begin{array}{c}\text { Isotope Activity } \\
\text { (nCi) }\end{array}$ \\
\hline${ }^{238} \mathrm{Pu}$ & 0.000815 & $1.394 \mathrm{E}+07$ \\
\hline${ }^{239} \mathrm{Pu}$ & 0.855498 & $5.298 \mathrm{E}+07$ \\
\hline${ }^{240} \mathrm{Pu}$ & 0.132172 & $2.994 \mathrm{E}+07$ \\
\hline${ }^{241} \mathrm{Pu}$ & 0.011210 & $0.0^{(\mathrm{a})}$ \\
\hline${ }^{242} \mathrm{Pu}$ & 0.000306 & $1.201 \mathrm{E}+03$ \\
\hline${ }^{241} \mathrm{Am}$ & 0.017833 & $6.115 \mathrm{E}+07$ \\
\hline Total & $1.018^{(\mathrm{b})}$ & $1.580 \mathrm{E}+08$ \\
\hline \multicolumn{3}{|c|}{$\begin{array}{l}\text { (a) Activity from this short-lived isotope not included in } \\
\text { total TRU activity. } \\
\text { (b) Weight fractions for the five Pu isotopes total } 1.00 \text {. }\end{array}$} \\
\hline
\end{tabular}

The neutron source term per $\mathrm{g}$ of $\mathrm{Pu}$ was found using the computer code SO1.580E+SOURCES (Wilson et al. 1999). This calculation summed the neutrons emitted by spontaneous fission from the six radionuclides, and evaluated the neutron emission rate resulting from $(\alpha, n)$ interactions with ${ }^{17} \mathrm{O}$ and ${ }^{18} \mathrm{O}$ in the $\mathrm{PuO}_{2}$ molecules. The neutron emission rate was found to be $250.3 \mathrm{n} / \mathrm{s}$ per $\mathrm{g} \mathrm{Pu} ; 44.7 \%$ from $(\alpha, \mathrm{n})$, and $55.3 \%$ from spontaneous fission. The average energy of neutrons emitted by $(\alpha, n)$ reactions was 2.325 MeV; the average energy from spontaneous fission was $1.935 \mathrm{MeV}$. A 23-group energy-binning scheme was used to model the energies of source neutrons.

The measured count rates in both cells were very close to zero, with large uncertainties, so there was no spatial variation in count rate to give an indication of non uniform TRU distribution in the hot cells. The first two calculation sets for each cell assumed that all the Pu was deposited in a single layer uniformly covering the top of a horizontal surface. One model placed all the contamination on the cast-iron floor of the hot cell, and the other placed all the contamination on the steel tray. These two distributions were chosen to provide upper and lower bounds of TRU estimates for the cells. The distribution on the tray placed the neutron emitters close to the detectors, and thus minimized the contamination quantity needed to produce the measured response. The distribution on the floor placed the neutron emitters farther from the detectors, maximizing the quantity needed to produce the measured response. For a third distribution, a "realistic" contamination pattern was chosen, with Pu distributed on hot cell surfaces according to scans of the cell taken with a gamma camera. 
For all cases, the total amount of TRU in the source region was $1 \mathrm{~g} \mathrm{Pu}$. This source quantity meant that calculated detector responses were on a "per g" basis, and the ratio of the measured to calculated responses would then be the quantity of contamination in the cell.

For the realistic contamination distribution in G Cell, Table 6.4 details the areas of contamination.

Table 6.4. Contamination regions in G Cell for "realistic" distribution.

\begin{tabular}{|c|c|c|c|}
\hline Contaminated Region & $\begin{array}{l}\text { Dimensions of } \\
\text { Contamination }\end{array}$ & $\begin{array}{c}\text { Relative } \\
\text { Source } \\
\text { Strength }\end{array}$ & $\begin{array}{l}\text { Quantity Pu in } \\
\text { Region (g) }\end{array}$ \\
\hline Spot on floor & 50-cm radius circle & 0.2 & 0.1099 \\
\hline Spot on tray & $50-\mathrm{cm}$ circle & 0.1 & 0.0550 \\
\hline Tray seam & $\begin{array}{l}\text { rectangular, } \\
50.8 \mathrm{~cm} \times 90 \mathrm{~cm}\end{array}$ & 0.1 & 0.0320 \\
\hline $\begin{array}{l}\text { Tray surface, other than } \\
\text { tray spot and tray seam }\end{array}$ & irregular shape, $49,174 \mathrm{~cm}^{2}$ & 0.04 & 0.1376 \\
\hline West wall, lower & $\begin{array}{l}\text { rectangular, } \\
81 \mathrm{~cm} \times 314.96 \mathrm{~cm}\end{array}$ & 0.04 & 0.0714 \\
\hline East wall, lower & $\begin{array}{l}\text { rectangular, } \\
81 \mathrm{~cm} \times 314.96 \mathrm{~cm}\end{array}$ & 0.04 & 0.0714 \\
\hline North wall, lower & $\begin{array}{l}\text { rectangular, } \\
195.58 \mathrm{~cm} \times 81 \mathrm{~cm}\end{array}$ & 0.04 & 0.0443 \\
\hline South wall, lower & $\begin{array}{l}\text { rectangular, } \\
195.58 \mathrm{~cm} \times 81 \mathrm{~cm}\end{array}$ & 0.04 & 0.0443 \\
\hline West wall, upper & $\begin{array}{l}\text { rectangular, } \\
101.27 \mathrm{~cm} \times 314.96 \mathrm{~cm}\end{array}$ & 0.06 & 0.1339 \\
\hline East wall, upper & $\begin{array}{l}\text { rectangular, } \\
101.27 \mathrm{~cm} \times 314.96 \mathrm{~cm}\end{array}$ & 0.06 & 0.1339 \\
\hline North wall, upper & $\begin{array}{l}\text { rectangular, } \\
101.27 \mathrm{~cm} \times 195.58 \mathrm{~cm}\end{array}$ & 0.06 & 0.0832 \\
\hline South wall, upper & $\begin{array}{l}\text { rectangular, } \\
101.27 \mathrm{~cm} \times 195.58 \mathrm{~cm}\end{array}$ & 0.06 & 0.0832 \\
\hline
\end{tabular}

The contamination regions were identified by examining scans from a gamma camera. The extent of contamination for each spot was based on the image on the scan, and the relative source strength was determined from the contour levels. The relative source strength had no values in an absolute sense, but the relative values could be used along with the area of each contamination region to allocate appropriate fractions of the hypothetical 1-g Pu inventory into each region. 
For H Cell, the contamination regions for the realistic distribution are given in Table 6.5.

Table 6.5. Contamination regions in H Cell for "realistic" distribution.

\begin{tabular}{|l|l|c|c||}
\hline Contaminated Region & \multicolumn{1}{|c|}{$\begin{array}{c}\text { Dimensions of } \\
\text { Contamination }\end{array}$} & $\begin{array}{c}\text { Relative Source } \\
\text { Strength }\end{array}$ & $\begin{array}{c}\text { Quantity Pu in } \\
\text { Region }(g)\end{array}$ \\
\hline Tray, center & $\begin{array}{l}\text { rectangular, } \\
162.56 \mathrm{~cm} \times 90 \mathrm{~cm}\end{array}$ & 0.0115 & 0.0770 \\
\hline West wall & $\begin{array}{l}\text { rectangular, } \\
128.3 \mathrm{~cm} \times 162.56 \mathrm{~cm}\end{array}$ & 0.026 & 0.2482 \\
\hline East wall & $\begin{array}{l}\text { rectangular, } \\
128.3 \mathrm{~cm} \times 162.56 \mathrm{~cm}\end{array}$ & 0.026 & 0.2482 \\
\hline North wall & $\begin{array}{l}\text { rectangular, } \\
128.3 \mathrm{~cm} \times 139.7 \mathrm{~cm}\end{array}$ & 0.026 & 0.2133 \\
\hline South wall & $\begin{array}{l}\text { rectangular, } \\
128.3 \mathrm{~cm} \times 139.7 \mathrm{~cm}\end{array}$ & 0.026 & 0.2133 \\
\hline
\end{tabular}

\subsection{Modeling Results}

For each MCNP calculation, tallies were collected in each detector tube that estimated the count rate that would actually be produced if the tube were counting in the neutron field being modeled. The MCNP calculations were allowed to run long enough until the uncertainty in the Monte Carlo algorithm was less than $2 \%$. The tallies for the three detectors were then summed to determine a count rate for the detector pod located in each modeled position. 
Table 6.6 presents the calculated count rates in G Cell, assuming $1 \mathrm{~g}$ Pu distributed in the cell. Results are presented for three different contamination scenarios.

Table 6.6. Modeled pod count rates in G Cell.

\begin{tabular}{||c|c|c|c|c||}
\hline Row / Col & $\begin{array}{c}\text { Distance from } \\
\text { Inside } \\
\text { East Wall (in) }\end{array}$ & $\begin{array}{c}\text { Contamination } \\
\text { on Cell Floor } \\
\text { (c/s per g Pu) }\end{array}$ & $\begin{array}{c}\text { Contamination } \\
\text { on Cell Tray } \\
\text { (c/s per g Pu) }\end{array}$ & $\begin{array}{c}\text { Realistic } \\
\text { Contamination in } \\
\text { Cell (c/s per g Pu) }\end{array}$ \\
\hline $\mathrm{r} 4$ / c1 & 26 & 0.00323 & 0.00417 & 0.00363 \\
\hline $\mathrm{r} 4$ / c1 & 56 & 0.00311 & 0.00418 & 0.00362 \\
\hline $\mathrm{r} 4$ / c5 & 11.5 & 0.00340 & 0.00441 & 0.00369 \\
\hline $\mathrm{r} 4$ / c5 & 34.25 & 0.00345 & 0.00452 & 0.00370 \\
\hline $\mathrm{r} 4$ / c5 & 48.5 & 0.00353 & 0.00451 & 0.00362 \\
\hline $\mathrm{r} 4$ / c5 & 66.5 & 0.00338 & 0.00449 & 0.00376 \\
\hline $\mathrm{r} 4$ / c12 & 11.625 & 0.00299 & 0.00398 & 0.00393 \\
\hline $\mathrm{r} 4$ / c12 & 21.125 & 0.00314 & 0.00412 & 0.00401 \\
\hline $\mathrm{r} 4$ / c12 & 31.5 & 0.00323 & 0.00418 & 0.00405 \\
\hline $\mathrm{r} 4$ / c12 & 49.5 & 0.00315 & 0.00418 & 0.00395 \\
\hline $\mathrm{r} 4$ / c12 & 66.5 & 0.00297 & 0.00399 & 0.00396 \\
\hline
\end{tabular}

Table 6.6 shows that the count rates are somewhat higher in the center of the cell than they are in the corners for the case of uniform contamination on the floor, but there is only a $16 \%$ difference between the highest count rate and the lowest. The tray contamination case also shows the lowest count rates in the corner and highest in the center, but the overall variation is within $12 \%$. For the realistic contamination case, the count rates at the south wall are higher than those at the north wall, but only by $11 \%$. These variations would thus be imperceptible in the actual measurements, where counting statistics uncertainties were typically well over $30 \%$. 
Table 6.7 shows the results of the MCNP calculations for $\mathrm{H}$ Cell, for the three contamination scenarios.

Table 6.7. Modeled pod count rates in H Cell.

\begin{tabular}{||c|c|c|c|c||}
\hline Row/Col & $\begin{array}{c}\text { Distance from } \\
\text { Inside East } \\
\text { Wall (in.) }\end{array}$ & $\begin{array}{c}\text { Contamination } \\
\text { on Cell Floor } \\
\text { (c/s per g Pu) }\end{array}$ & $\begin{array}{c}\text { Contamination } \\
\text { on Cell Tray } \\
\text { (c/s per g Pu) }\end{array}$ & $\begin{array}{c}\text { Realistic } \\
\text { Contamination in } \\
\text { Cell (c/s per g Pu) }\end{array}$ \\
\hline r4/c1 & 10.125 & 0.00557 & 0.01015 & 0.00819 \\
\hline $\mathrm{r} 4 / \mathrm{c} 1$ & 28.7 & 0.00588 & 0.01061 & 0.00808 \\
\hline $\mathrm{r} 4 / \mathrm{c} 1$ & 45.5 & 0.00553 & 0.01009 & 0.00823 \\
\hline $\mathrm{r} 4 / \mathrm{c} 3$ & 19.5 & 0.00620 & 0.01128 & 0.00750 \\
\hline $\mathrm{r} 4 / \mathrm{c} 3$ & 28.5 & 0.00619 & 0.01124 & 0.00754 \\
\hline $\mathrm{r} 4 / \mathrm{c} 3$ & 38 & 0.00611 & 0.01113 & 0.00749 \\
\hline $\mathrm{r} 4 / \mathrm{c} 6$ & 10.25 & 0.00565 & 0.01044 & 0.00823 \\
\hline $\mathrm{r} 4 / \mathrm{c} 6$ & 28.5 & 0.00585 & 0.01070 & 0.00819 \\
\hline $\mathrm{r} 4 / \mathrm{c} 6$ & 45.5 & 0.00553 & 0.01036 & 0.00824 \\
\hline
\end{tabular}

The count rate patterns in $\mathrm{H}$ Cell are similar to those in G. For the two uniform contamination cases, the count rates in the center of the cell are higher than in the corners. For the realistic contamination, the highest results were nearest the walls, since the walls were assumed to be contaminated. 


\subsection{Estimates of TRU Quantities in the Hot Cells}

Since the MCNP calculations were performed with a total Pu inventory of $1 \mathrm{~g}$, the calculated detector responses were in units of $\mathrm{c} / \mathrm{s}$ per gram $\mathrm{Pu}$. Thus the adjustment between measurements and calculations can be done by dividing the measured count rates by the calculated count rates - the result of this operation is the cell inventory of $\mathrm{Pu}$, in grams.

Table 5.2 lists 15 measured count rates for G Cell, but 4 of these should be ignored because they were performed on a day when a cask containing Pu was located outside the cell, unintentionally elevating the dose rate. The remaining 11 count rates can be averaged, giving a count rate of $0.0045 \mathrm{c} / \mathrm{s}$. This averaging assumes a uniform count rate distribution in the cell, which is consistent with the counts and their uncertainties. For H Cell, six count rates can be averaged (omitting five with elevated count rates from the cask containing $\mathrm{Pu}$ ) to get an average count rate of $0.0082 \mathrm{c} / \mathrm{s}$.

The calculated count rates can also be averaged, since the variation in these count rates is smaller than the counting statistics uncertainties for the measurements.

Table 7.1 presents the calculated inventories for $\mathrm{G}$ and $\mathrm{H}$ Cells, using the measured count rates and the calculated values for each of the source distributions.

Table 7.1. Estimated Pu inventories in $\mathrm{G}$ and $\mathrm{H}$ Cells.

\begin{tabular}{|c|c|c|c|c|c|}
\hline Cell & $\begin{array}{c}\text { Average } \\
\text { Measured } \\
\text { Count Rate } \\
\text { (c/s) }\end{array}$ & $\begin{array}{l}\text { Assumed Source } \\
\text { Distribution }\end{array}$ & $\begin{array}{c}\text { Average } \\
\text { Calculated } \\
\text { Count Rate } \\
\text { (c/s per } \mathbf{g} \text { Pu) }\end{array}$ & $\begin{array}{c}\text { Estimated } \\
\text { Cell TRU } \\
\text { Inventory } \\
\text { (g Pu) }\end{array}$ & $\begin{array}{c}\text { Estimated Cell } \\
\text { TRU Activity } \\
\text { (nCi/g) }\end{array}$ \\
\hline \multirow{3}{*}{ G } & \multirow{3}{*}{0.0045} & uniform on floor & 0.0032 & 1.39 & 2.75 \\
\hline & & uniform on tray & 0.0042 & 1.06 & 2.10 \\
\hline & & $\begin{array}{l}\text { realistic, based on } \\
\text { gamma camera } \\
\text { scans }\end{array}$ & 0.0038 & 1.18 & 2.34 \\
\hline \multirow{3}{*}{$\mathrm{H}$} & \multirow{3}{*}{0.0082} & uniform on floor & 0.0058 & 1.41 & 5.28 \\
\hline & & uniform on tray & 0.0107 & 0.77 & 2.89 \\
\hline & & $\begin{array}{l}\text { realistic, based on } \\
\text { gamma camera } \\
\text { scans }\end{array}$ & 0.0080 & 1.03 & 3.87 \\
\hline
\end{tabular}


Using the values of cell inventories shown in Table 7.1, estimates of TRU activity in the cell, as a function of total cell mass, can be found using the following data:

- TRU specific activity: $1.580 \times 10^{8} \mathrm{nCi} / \mathrm{g} \mathrm{Pu}$, as shown in Table 6.3

- Mass of G Cell: $79,876 \mathrm{~kg}$

- Mass of H Cell: $42,083 \mathrm{~kg}$.

These estimates of TRU activity in the cells are presented in Table 7.1.

\subsection{Uncertainties}

A number of uncertainties can be identified with this analysis, relating to calibration, modeling, detector positioning, data interpretation, assumptions about the composition of contamination, and other operational unknowns. Dominating the uncertainty, however, are two factors: counting statistics uncertainty and uncertainty in the background. The counting statistics uncertainties are high, because a small number of events was recorded in each measurement. The uncertainty in the background was high because it is difficult to assess the true background count rate inside a cell.

For counting statistics, the estimate of uncertainty is about $0.0020 \mathrm{c} / \mathrm{s}$ for measurements in both $\mathrm{G}$ and $\mathrm{H}$ Cells. This estimate is based on the total neutron counts for groups of five or six measurements, since these are added together to obtain the averaged measured count rates in Table 7.1. Thus the counting statistics uncertainty would range from $24 \%$ to $44 \%$.

However, the uncertainty introduced by interpretation of the background could be much higher. It is possible that all of the measured neutron counts inside the hot cell were generated by cosmic radiation interactions with the iron cell walls, in which case the neutron count rates from TRU would be zero and the estimated TRU inventory would be zero for both cells. At the upper end of the uncertainty range, it could be assumed that no neutron counts were caused by nuclear interactions in the iron, and the background would be described by the measured count rates outside the cell, attenuated by neutron transport through the cell walls. An MCNP calculation shows that a neutron flux recorded between hot cells would be reduced by a factor of 0.3185 as it moved into the cell. Using this adjustment for the background, the average measured count rate in G Cell would be $0.0125 \mathrm{c} / \mathrm{s}$ (compared to $0.0045 \mathrm{c} / \mathrm{s}$ in Table 7.1), and the average measured count rate in $\mathrm{H}$ Cell would be $0.0163 \mathrm{c} / \mathrm{s}$ (compared to $0.0082 \mathrm{c} / \mathrm{s}$ in Table 7.1). This upper bound gives TRU inventory estimates that are higher by a factor of 2.8 for G Cell and 2.0 for $\mathrm{H}$ Cell. 
Using upper and lower bounds derived from the uncertainties in counting statistics and background, bounding values can be put on the TRU estimates as shown in Table 7.2.

Table 7.2. Best estimates and upper/lower bound estimates for TRU inventories.

\begin{tabular}{|c|l|c|c||}
\hline Cell & \multicolumn{1}{|c||}{ Condition } & $\begin{array}{c}\text { Estimated Cell } \\
\text { TRU Inventory } \\
(\mathbf{g ~ P u})\end{array}$ & $\begin{array}{c}\text { Estimated Cell TRU } \\
\text { Inventory (nCi/g) }\end{array}$ \\
\hline $\mathrm{G}$ & $\begin{array}{l}\text { Lower bound estimate - assume all neutron } \\
\text { counts from nuclear interactions in cell walls }\end{array}$ & 0.00 & 0.00 \\
\hline $\mathrm{G}$ & $\begin{array}{l}\text { Best estimate - realistic source distribution, } \\
\text { Table 4.1 }\end{array}$ & 1.18 & 2.34 \\
\hline $\mathrm{G}$ & $\begin{array}{l}\text { Upper bound estimate - assume lowest } \\
\text { possible background, uniform source on floor }\end{array}$ & 2.75 & 7.67 \\
\hline $\mathrm{H}$ & $\begin{array}{l}\text { Lower bound estimate - assume all neutron } \\
\text { counts from nuclear interactions in cell walls }\end{array}$ & 0.00 & 0.00 \\
\hline $\mathrm{H}$ & $\begin{array}{l}\text { Best estimate - realistic source distribution, } \\
\text { Table 4.1 }\end{array}$ & 1.03 & 3.87 \\
\hline $\mathrm{H}$ & $\begin{array}{l}\text { Upper bound estimate - assume lowest } \\
\text { possible background, uniform source on floor }\end{array}$ & 2.80 & 10.49 \\
\hline
\end{tabular}

\subsection{Minimum Detectable Level}

Using the measured background counts and the sample counting time, a minimum detectable mass (MDM) can be calculated. Typically radiation counting defines a minimum detectable activity, but this concept can be altered slightly for our application since TRU activity can be translated directly to TRU mass. The MDM can be found using Equation 7.1 (Hickey et al. 1993):

$$
M D M=\frac{2.71+3.29 \sqrt{S_{b}\left(1+\frac{T_{b}}{T_{s}}\right)}}{T_{b} k}
$$

where:

$$
\begin{aligned}
& \text { MDM = minimum detectable mass of } \mathrm{Pu}(\mathrm{g}) \\
& \mathrm{S}_{\mathrm{b}}=\text { total number of background counts collected } \\
& \mathrm{T}_{\mathrm{b}}=\text { time of collection of background counts }(\mathrm{s}) \\
& \mathrm{T}_{\mathrm{s}}=\text { time of collection of sample counts }(\mathrm{s}) \\
& \mathrm{k}=\text { conversion factor, } \mathrm{c} / \mathrm{s} \text { to gram } \mathrm{Pu}
\end{aligned}
$$


For G Cell, the MDM should be considered for two separate cases, since two different backgrounds were used. For the measurements in column 5 and column 9, the background measurement collected 40 counts in 4590 seconds, and the MDM was found to be $1.82 \mathrm{~g} \mathrm{Pu}$, assuming realistic contamination distribution. For the measurements in columns 1 and 12, the appropriate background measurement had collected 113 counts in 7923 seconds, so the MDM was found to be $1.94 \mathrm{~g} \mathrm{Pu}$, assuming the realistic distribution.

For H Cell, all measurements used a single background count, with 798 counts collected in 67,077 seconds. The MDM was $0.64 \mathrm{~g} \mathrm{Pu}$ for this measurement.

Note that for G Cell, the MDM values of 1.82 and $1.94 \mathrm{~g}$ Pu are above the best estimate of $1.08 \mathrm{~g} \mathrm{Pu}$. The amount of $1.94 \mathrm{~g}$ Pu corresponds to an activity per unit mass of $3.8 \mathrm{nCi} / \mathrm{g}$. Thus, if the interpretation of background used in the "best estimate" for G Cell is accepted, we cannot reliably quantify a value less than $1.9 \mathrm{~g}$ Pu or $3.8 \mathrm{nCi} / \mathrm{g}$. For $\mathrm{H}$ Cell, however, the MDM of $0.64 \mathrm{~g}$ is below the best estimate of $1.03 \mathrm{~g}$ $\mathrm{Pu}$, so this best estimate is valid. The difference is the long background count that was used for the $\mathrm{H}$ Cell measurements.

This discussion of minimum detectable mass is based on the best-estimate interpretation of background - that the neutron count rate measured outside the cell is a good estimate of the background neutron count rate inside the cell. There is still the possibility of an explanation that all of the neutron counts recorded inside the cell were caused by cosmic radiation interaction with cell wall atoms, meaning that the TRU content may be zero. This study did not rule out this zero interpretation. 


\subsection{Conclusions}

The neutron pod analysis gave TRU inventory estimates of just about $1 \mathrm{~g}$ Pu for each hot cell inventory:

- For G Cell, the best estimate is $1.18 \mathrm{~g} \mathrm{Pu}$, which translates into $2.34 \mathrm{nCi} / \mathrm{g}$ for the Pu activity in a waste package, using the mass of the entire cell as the total waste mass. The lower bound for this estimate is zero, and the upper bound is $2.75 \mathrm{~g} \mathrm{Pu}(7.67 \mathrm{nCi} / \mathrm{g})$.

- For $\mathrm{H} \mathrm{Cell}$, the best estimate is $1.03 \mathrm{~g} \mathrm{Pu}(3.87 \mathrm{nCi} / \mathrm{g})$, with a lower bound of zero and an upper bound of $2.80 \mathrm{~g} \mathrm{Pu}(10.5 \mathrm{nCi} / \mathrm{g})$.

The best estimates of TRU inventory were based on neutron counts inside the hot cells, then modeling each cell using a Pu distribution that was based on gamma camera scans. Neutron count rates observed in both cells were very near background levels, and counting statistics uncertainties were high — many of the individual measurements had counting statistics uncertainties of $100 \%$ or more, and when averaged to use them in a data analysis, these uncertainties ranged from $24 \%$ to $44 \%$.

However, a larger source of uncertainty was the interpretation of the neutron background in the hot cell, and alternate interpretations of background were used to derive the lower and upper bound estimates for TRU inventory in the cells. For the best estimate, it was assumed that the background neutron count rate would be identical to the background measured outside the cell; for the lower bound it was assumed that all of the counts recorded in the cell were created by cosmic radiation interacting with iron in the cell walls and ceiling; and for the upper bound estimate, it was assumed that no background neutrons were generated in the cell walls, but rather the background rate measured outside a cell wall was attenuated by neutrons passing through the cell wall. Based on observations made by people counting neutrons in cells at Hanford, the lower-bound estimate is more credible than the upper-bound estimate.

One reason that the count rates were low in these measurements was the choice of neutron detector. The fission chamber was chosen because it is insensitive to gamma radiation. The other likely detector would be a ${ }^{3} \mathrm{He}$ tube, which has a much better sensitivity to neutron radiation, but is susceptible to gamma interference. Since some of the hot cells in the 327 Building Canyon may have sufficient radioactive contamination to overwhelm a ${ }^{3} \mathrm{He}$ detector with gammas, fission chambers were chosen for the detector pod. For $\mathrm{G}$ and $\mathrm{H}$ Cells only, a ${ }^{3} \mathrm{He}$ detector may have been a better choice, but the fission chambers allow the pod to be used in all cells in the canyon.

The other major uncertainty, interpreting the background, is a difficult one, because no data exists to relate the background count rate outside a cell to the count rate inside it. A future study that could help with this interpretation could be performed at Hanford's Whole Body Counter. There is a lowbackground room in that facility with walls and ceiling made of old battleship steel, and it is free of contamination. If the pod were used to count background counts inside the room and outside of it, it would give a comparison that would show the contribution of cosmic ray interactions in the steel walls and ceiling to neutron count rate. 
Although the uncertainties are high as a fraction of the estimated TRU quantities, the conclusions about the low inventory of $\mathrm{Pu}$ in each cell is still valid. An extreme upper bound estimate of the inventory in $\mathrm{H}$ Cell would give $10.5 \mathrm{nCi} / \mathrm{g}$, whereas the upper bound estimate for $\mathrm{G}$ Cell is $7.7 \mathrm{nCi} / \mathrm{g}$. In any case, the values are well below the $100 \mathrm{nCi} / \mathrm{g}$ level.

The neutron pod provides an efficient system for measuring neutrons, even in the presence of a high gamma background. Design features, including the use of polyethylene for the traverse pipe, optimize the sensitivity of the detectors to neutrons. Care must be taken during measurements to ensure that sufficient counts are collected to provide good counting statistics.

The calibration tests showed good reproducibility, even when the pod is rotated. Table 3.2 shows that the variation in count rate is only $0.4 \%$ when the pod is rotated to a different position. This shows that the three detectors have identical responses and are positioned symmetrically inside the pod. Thus there is no need to account for the pod's directionality (rotating about its axis) when using the pod in a hot cell.

The modeling results showed excellent agreement with the calibration measurements. Twenty-two different measurements were included in the analysis, using two different neutron sources, in both unmoderated and moderated configurations, and with the pod inside the outer pipe and without the pipe covering it. When comparing the measured count rates to the modeled values, as shown in Table 4.2 the agreement between measured and modeled values ranged from 0.1 to $13.5 \%$. If the tally conversion constant (discussed in Section 4.4) had been chosen to put the modeled values in the middle of the range of measured values, rather than at one extreme, the disagreements would have ranged from $-6.6 \%$ to $+6.6 \%$. However, the conversion constant was chosen based on an earlier measurement, and it is possible that a measurement bias, such as positioning of the platform supporting the pod in the LSR, caused this $6 \%$ bias.

The calibration and modeling effort accomplished the following objectives:

- validated the tally conversion constant used in the MCNP models

- validated the models for a variety of neutron spectra and pod/pipe configurations.

The calibration and modeling effort provides a good level of confidence that a pod measurement, inside a hot cell, followed by modeling of the pod in the cell, will provide a reliable estimate of the neutron emission rate from a source inside the hot cell. This estimate must be based on an assumption about the location of the source, and it cannot provide any information on the isotopic composition of the neutron emitters in the hot cell.

However, a set of pod measurements, with the pod located in various positions in the cell, can provide input to MCNP modeling that can verify an assumption about the locations of neutron emitters in the cell. This assumption can be based initially on other information, including knowledge of the processing history of the cell, survey measurements, and gamma camera images. The output of an MCNP run can then be compared to the pod measurement data to test this distribution assumption and suggest changes to the distribution pattern that can be used in a second model run. This cycle can be iterated several times 
until the assumed distribution, used in the MCNP model, produces pod count rates that match the values actually recorded, within reasonable uncertainties. The final distribution can also be used to arrive at an overall quantity of neutrons emitted.

After the neutron emissions in the hot cell are determined, the total TRU quantity in the cell can be determined using knowledge of the isotopic composition of contaminants identified in the cell. 
PNNL-14178

\subsection{References}

Briesmeister, JF, Ed. 2000. MCNP - A General Monte Carlo N-Particle Transport Code, Version 4C. LA-13709-M. Los Alamos National Laboratory, Los Alamos, New Mexico.

Haggard, DL, JE Tanner, GM Mapili, A Mozhayev, and A Savlov. 1998. "Neutron Coincidence Counting of Plutonium or Is It High Energy Muon Induced Time Correlated Events in Lead." Pacific Northwest National Laboratory, Richland, Washington. Presented at and published in the 1998 Proceedings of the Institute of Nuclear Materials Management.

Hickey, EE, GA Stoetzel, DJ Strom, GR Cicotte, CM Wiblin, and SA McGuire. 1993. Air Sampling in the Workplace. NREG-1400. US Nuclear Regulatory Commission, Washington, DC 20555.

Wilson, WB, RT Perry, WS Charlton, TA Parish, GP Estes, TH Brown, ED Arthur, M Bozoian, TR England, DG Madland, and JE Stewart. 1999. SOURCES4A: A Code for Calculating ( $\alpha, n)$, Spontaneous Fission, and Delayed Neutron Sources and Spectra. LA-13639-MS. Los Alamos National Laboratory, Los Alamos, New Mexico. 


\section{Distribution}

No. of

Copies

ONSITE

DOE Richland Operations Office

R. A. Pressentin

8 Pacific Northwest National Laboratory

D. L. Haggard

G.M. Mapili (2)

R. I. Scherpelz (4)

J. E. Tanner

3 Other Hanford

D. S. Dutt

R. W. Stevens

W. Jasen

Distr. 1 